\title{
Liver Function in Novel Coronavirus Disease (COVID-19): A Systematic Review and Meta-Analysis
}

\author{
Mohammad Zahedi ${ }^{1}$, Mohammad Yousefi ${ }^{2}$, Mahdi Abounoori ${ }^{3}$, Mohammad Malekan $^{3}$, \\ Fatemeh Tajik ${ }^{4}$, Keyvan Heydari ${ }^{3,8}$, Parham Mortazavi ${ }^{5}$, Monireh Ghazaeian ${ }^{6 *}$, Fateme \\ Sheydaee $^{2}$, Amirreza Nasirzadeh ${ }^{7}$, Reza Alizadeh-Navaei ${ }^{8 *}$
}

1. Department of Laboratory Sciences, School of Allied Medical Science, Student Research Committee, Mazandaran University of Medical Sciences, Sari, Iran.

2. Department of medicine, Faculty of Medicine, Semnan University of Medical Sciences, Semnan, Iran

3. Student Research Committee, School of Medicine, Mazandaran University of Medical Sciences, Sari, Iran.

4. Medical student, Faculty of Medicine, Azad University of Tehran, Tehran, Iran

5. Student Research Committee, School of Pharmacy, Mazandaran University of Medical Sciences, Sari, Iran.

6. Department of Clinical Pharmacy, Faculty of Pharmacy, Mazandaran University of Medical Sciences.

7. Student of Basic Sciences in Nursing, Student Research Committee, Gonabad University of Medical Sciences, Gonabad, Iran.

8. Gastrointestinal Cancer Research Center, Mazandaran University of Medical Sciences, Iran.

\section{Corresponding author:}

1 st: Monireh Ghazaeian, Department of Clinical Pharmacy, Faculty of Pharmacy, Mazandaran University of Medical Sciences. ghazaeianm@gmail.com

2 st: Reza Alizadeh-Navaei, Gastrointestinal Cancer Research Center, Mazandaran University of Medical Sciences, Iran.reza_nava@yahoo.com

Running title: Liver Function in Novel Coronavirus Disease 


\begin{abstract}
Introduction:The outbreak of new coronavirus has become a global public health challenge. Given a consequential liver function, and the high risk of death coming from liver disorders, the assessment of Novel Coronavirus Disease on liver function is importance. Hence, we carried out this meta-analysis to heightening insight into the occult features of COVID 19, which is likely to affect liver function.
\end{abstract}

Method:This study was performed using databases of Web of Science, Scopus, and PubMed. We considered English cross-sectional and case-series papers, which reported available findings on the association between liver injury and COVID-19 infection. We used the STATA v.11 and random effect model for data analysis.

Result:In this present meta-analysis, 52 papers, including 8,463 COVID-19 patients, were studied. The prevalence of increased liver enzymes among the patients, including Alanine aminotransferase, Aspartate aminotransferase, were $30 \%$ and $21 \%$ in non-severe patients, respectively, which were $38 \%$ and $48 \%$ in severe patients. The prevalence of increasing Creactive protein, Lactate dehydrogenase, D-dimer, and Bilirubin were 55\%, 39\%, 28\%, and $10 \%$ in non-severe patients respectively, which were $78 \%, 75 \%, 79 \%$ and $17 \%$ in sever patients. The prevalence of liver toxicity as a complication of COVID-19 was 20\%.Also patients who have severe condition are 5.54, 4.22, 4.96, 4.13 and 4.34 times more likely to have elevated CRP, ALT, AST, LDH, D-dimer enzymes retrospectively .

Conclusion:Elevation of some liver markers were higher in patients with severe COVID-19 infection. All to gather, we assumed that abnormal liver markers could act as a prognostic factor for a better survey of COVID-19.

Keywords: COVID-19, SARS-CoV-2, Liver Function, Liver 


\section{Introduction:}

The outbreak of a new virus, called the 2019 novel coronavirus (2019 n-COV), has been led to many worries amid all strata of populations, especially the vast majority of health care workers (1). By 11 May 2020, a considerable proportion of the population, approximately 4006257 , was detected as Coronavirus cases, and the rate of death Toll, relatively 278892 , reported. The rate of mortality and new cases highly progress especially, among the vast spectrum of the population comprised of older people (2). $2019 \mathrm{n}-\mathrm{COV}$, in the family coronaviridae, are enveloped, single-stranded positive RNA viruses with different diameters from 60 to $140 \mathrm{~nm}$ (3) entered into target cells by binding spike (S) protein to angiotensin-converting enzyme 2 (ACE2) receptor (4). Transmission of this virus is human to human through close contacts or droplets and also feces $(5,6)$. Health care workers fundamentally deal with the assortment of clinical characteristics that appeared among different patients. Many people are either asymptomatic or mildly symptomatic. The most common clinical features of symptomatic patients consisting of cough, fever, expectoration, myalgia or fatigue, malaise, sore throat, headache, diarrhea, and rarely hemoptysis and vomiting. And also, in severe cases shows a set of shortness of breath and dyspnea (7-12). Some infected patients would suffer from liver dysfunction. Based on a series of studies working on this issue, the changes in liver enzymes among patients, particularly in severe cases, were revealed (13-17). Given a consequential liver function, and the high risk of death coming from liver disorders, the assessment of Novel Coronavirus Disease (COVID-19) on liver function is of significant importance among health care workers (17-19). Also through a recent study on liver enzyme changes during COVID-19 this fact that higher levels of Aspartate aminotransferase (AST), and direct Bilirubin increases the transfer risk to intensive and critical care units, have been stated. It is reported that the AST level of 30.5 (U/L) had a sensitivity of $71.4 \%$ and specificity of $68.5 \%$ for critical and intensive care transfer (20). Moreover, In a similar study with us, elevated Serum levels of Aspartate aminotransferase, Alanin aminotransferase (ALT), total Bilirubin, and lower levels of Albumin were observed in severe cases (21).

Recent studies on liver function during COVID-19 were not comprehensive, and liver function was not compared with the severity of the disease. This research has reviewed the epistemological and evidential resources on the correlation between COVID-19 and the function of the liver. Hence, we carried out this systematic review and meta-analysis to heightening insight into the occult features of COVID 19, which is likely to affect liver function. 


\section{Method:}

\section{Search strategy}

The results and their analysis in this study were reported according to the Preferred Reporting Items for Systematic Reviews and Meta-Analyses (PRISMA). We conducted a systematic review and meta-analysis of cross-sectional and case-series studies. Search engines and databases, including Web of Science, Scopus, and PubMed without any time limitation for publications up to April 19, 2020. As a manual search, the list of imported references, a list of related reviews, and the results of Google Scholar have been investigated. The search process was done by two researchers using the following medical subject headings (22) keywords: "2019 novel coronavirus infection" OR COVID19 OR COVID-19 OR "coronavirus disease 2019" OR "coronavirus disease-19" OR "2019-nCoV disease" OR "2019 novel coronavirus disease" OR "2019-nCoV infection" OR "SARS COV-2" OR SARS-COV-2, in combination with "Liver function" OR AST OR ALT OR "Liver toxicity" OR Bilirubin OR INR OR SGOT OR "Aspartate transaminase" OR "Alanine transaminase" OR SGPT OR ALP OR AFP OR liver OR hepat*, which were also combined with and/or/not to find more articles. As a manual search, the list of imported references, list of related reviews, have been investigated.

\section{Eligibility Criteria}

We considered the following criteria for study selection:

1) The study should have an observatory approach investigated COVID-19 patients;

2) Studies on a particular group of people (e.g., pregnant women) has been excluded;

3) Studies included with assessing the association between serum levels of Alanine aminotransferase (ALT), Aspartate aminotransferase (AST), Albumin, Bilirubin, C-Reactive protein, ESR, D-dimer, LDH and severe outcome from COVID-19 infection as the major outcomes of interest and reported median (IQR) for serum levels of AST, ALT, Albumin, Bilirubin in both severe and non-severe COVID-19 infected patients.

4) Studies should be in English. English abstracts of other language studies were investigated for eligible data.

Studies that had incomplete data for any reason and all the case reports, expert opinion articles, review articles, books, and animal studies were excluded.

\section{Study Selection}

Duplicated papers were deleted using EndNote software (version X8, Thomson Reuters, Philadelphia, USA). Two of the authors reviewed the remaining papers according to the criteria, separately. Titles and abstracts were screened for initial study inclusion, with a fulltext review when the abstract was insufficient to determine if the study encountered the inclusion or exclusion criteria. In case of disagreement between the two investigators, a third person was making the final decision. 


\section{Quality assessment}

For the quality assessment, two members of our team independently valued the selected articles using the modified version of Newcastle-Ottawa Quality Assessment (NOS) and NIH quality assessment tool for case series. The investigated papers categorized into three categories. The studies with a score of 1 or 2 as poor quality, 3 to 6 as moderate quality and studies with a score of 7 to 9 as high quality.

\section{Data Extraction}

Data such as author's information, publication year, study design, sample size, average/median age and gender of patients, serum levels of CRP, LDH, D-dimer, ESR, AST, ALT, Albumin, and Bilirubin have been extracted and recorded.

\section{Statistical Analysis}

Statistical analysis was performed using STATA v.11 software. The heterogeneity of studies has been investigated using the I-square (I2) test. Based on the results, for I2 more than $50 \%$, we used a random-effects model to pool the results. Moreover, to study the heterogeneity of the added study, subgroup analysis in severe and non-severe patients has been done.

\section{Results}

\section{Study Selection Process}

The search in three databases, including Web of Science, Scopus, and PubMed yields 351 results, and for other sources like google, scholar yields 643 results. After excluding 341 duplicated papers, 663 records were admitted to the screening step. Then, 92 papers have been selected for full-text eligibility assessment. Finally, 58 studies were entered into the metaanalysis. Also, ten studies from other sources were included in the meta-analysis. The PRISMA folw diagram for the study selection process presented in Figure 1.

\section{Study Characteristics}

Among selected papers, a total of 8463 patients infected with CoVID-19 with age ranged between 1.5 to 90 years o--ld were included in our investigation, and all of the studies were conducted in China. Characteristics of studies entered into meta-analysis are presented in Table 1.

\section{Quality Assessment}

For quality assessment, the NOS tool for cross-sectional studies and NIH quality assessment tools for case series were conducted.

\section{Characteristics of Patients}

Findings showed that $80 \%$ of the patients needed inpatient care services, and $27 \%$ were admitted to the Intensive care unit. (Fig. 3) About 50\% of patients were discharged; however, $16 \%$ of patients were expired (Fig. 4) 


\section{Laboratory Findings}

Regarding laboratory findings in patients infected with COVID-19 most common observation was increasing erythrocyte sedimentation rate (ESR), C-reactive protein (CRP), and Lactate dehydrogenase (LDH) which were reported in 9, 18 and 18 studies. Meta-analysis findings are as follows respectively: $57 \%(95 \% \mathrm{Cl}, 44-70), 53 \%(95 \% \mathrm{Cl}, 43-62)$ and $36 \%(95 \% \mathrm{Cl}, 25-$ 47). (Fig. 5, and Fig. 6).

Alanine aminotransferase (ALT), Aspartate aminotransferase (AST), D-dimer, total Bilirubin increasing levels in patients were reported in 20,19,17, and 8 studies with the prevalence of $17 \%(95 \% \mathrm{Cl}, 13-21), 18 \%(95 \% \mathrm{Cl}, 14-23), 35 \%$ (95\% Cl, 24-47), and $12 \%$ (95\% Cl, 7-17) (Fig. 5 and Fig 6). Also decreasing of Albumin level were investigated in 6 studies with prevalence of $(44 \%, 95 \% \mathrm{Cl}, 0-88)$.

Figure 2 shows the risk estimates results from the random-effect model combining the odds ratios (ORs) for laboratory findings between covid_19 severe and non-severe patients. CRP increase $(\mathrm{OR}=5.54,95 \% \mathrm{CI}=2.67-11.49, \mathrm{p}=0.002)$, ALT increase $(\mathrm{OR}=4.22,95 \% \mathrm{CI}=1.01$ 17.66, $\mathrm{p}=0.00)$, AST increase $(\mathrm{OR}=4.96,95 \% \mathrm{CI}=2.18-11.3, \mathrm{p}=0.00), \mathrm{LDH}$ increase $(\mathrm{OR}=$ $4.13,95 \% \mathrm{CI}=1.64-10.42, \mathrm{p}=0.045)$, D-dimer increase $(\mathrm{OR}=4.34,95 \% \mathrm{CI}=1.7-11.09$, $\mathrm{p}=0.00)$, Liver toxicity $(\mathrm{OR}=1.67,95 \% \mathrm{CI}=0.20-15.86, \mathrm{p}=0.00)$

\section{Comorbidities}

Different comorbidities were investigated in patients with COVID-19. Hypertension, diabetes, and cardiovascular disease were the most prevalent comorbidities among patients with a prevalence of $24 \%$ (95\% Cl, 19-29), $15 \%(95 \% \mathrm{Cl}, 11-18)$ and $10 \%(95 \% \mathrm{Cl}, 8-12)$ that were investigated in 34,35 and 32 studies respectively (Fig.7, Fig. 8 and Table 2).

Other disorders prevalence was as follows: Cerebrovascular disease 3\% (95\% Cl, 2-4), digestive system disease $4 \%(95 \% \mathrm{Cl}, 2-6)$, chronic liver disease 3\% (95\% Cl, 2-4), malignancy $7 \%(95 \% \mathrm{Cl}, 1-12)$, respiratory system disease 3\% (95\% Cl, 2-4), chronic kidney disease 1\% ( $95 \% \mathrm{Cl}, 1-2)$, endocrine system disease $8 \%(95 \% \mathrm{Cl}, 4-12)$, immunodeficiency $1 \%(95 \% \mathrm{Cl}$, $0-1)$ and CNS disease $1 \%(95 \% \mathrm{Cl}, 0-3)$ respectively (Fig.7, Fig.8, Fig.9, Fig.10 and Table 2). Pneumonia, acute respiratory distress syndrome (ARDS), acute kidney injury, and shock after infecting with COVID-19 have been investigated in 3, 6, 6, and 6 studies, respectively. Metaanalysis showed the prevalence of $35 \%(95 \% \mathrm{Cl},-28-98), 28 \%(95 \% \mathrm{Cl}, 15-40), 8 \%(95 \% \mathrm{Cl}$, 4-13) and 3\% (95\% Cl, 1-5) respectively (Fig5, Fig.10 and Table 2). Also, liver toxicity as a complication of COVID-19 was reported in 13 studies with the prevalence of $(20 \%, 95 \% \mathrm{Cl}$, 14-26).(Fig.5)

\section{Clinical outcomes of patients based on the severity}

The meta-analysis showed that the prevalence of mortality among non-severe patients was $0 \%$ $(95 \% \mathrm{Cl}, 0-1)$, whereas $50 \%(95 \% \mathrm{Cl}, 39-60)$ in severe patients. Furthermore, the prevalence of discharged patients among non-severe cases were $43 \%(95 \% \mathrm{Cl}, 1-84)$, which were $29 \%$ $(95 \% \mathrm{Cl}, 21-37)$ in severe cases (Supplementary File and Table 2). 
medRxiv preprint doi: https://doi.org/10.1101/2020.05.20.20108357; this version posted May 23, 2020. The copyright holder for this preprint (which was not certified by peer review) is the author/funder, who has granted medRxiv a license to display the preprint in perpetuity.

All rights reserved. No reuse allowed without permission.

\section{Laboratory findings based on the severity of the disease}

In this systematic review, we analyzed the subgroups based on the severity of the disease for finding the source of heterogeneity. The results are as follows:

The prevalence of increased liver enzymes among the patients, including ALT and AST were $30 \%$ and $21 \%$ in non-severe patients, respectively, which were $38 \%$ and $48 \%$ in severe patients (Supplementary File and Table 2).

The meta-analysis showed that the prevalence of increasing other laboratory findings like CRP, LDH, D-dimer, and Bilirubin were 55\%, 39\%, 28\%, and 10\% in non-severe patients respectively, which were $78 \%, 75 \%, 79 \%$ and $17 \%$ in sever patients. Also, the prevalence of decreasing albumin in severe patients was $36 \%$, and the prevalence of liver toxicity among non-sever patients was $17 \%$, whereas $41 \%$ in severe patients. (Supplementary File and Table 2).

\section{Comorbidities based on the severity of the disease}

The prevalence of comorbidities such as hypertension, diabetes, and cardiovascular disease was $13 \%, 7 \%$, and $4 \%$ in non-severe patients, respectively. However, these statistics were 38\%, $26 \%$, and $16 \%$, respectively (Supplementary File and Table 2).

The prevalence of other underlying diseases like malignancy, digestive system disease, chronic liver disease, immunodeficiency, chronic kidney disease, and cerebrovascular disease were $1 \%, 8 \%, 4 \%, 0 \%, 0 \%$ and $1 \%$ in non-severe patients respectively whereas in severe patients were $3 \%, 12 \%, 6 \%, 7 \%, 3 \%$ and $7 \%$ (Supplementary File and Table 2).

\section{Discussion}

The novel coronavirus 2019, which named SARS-Cov-2, shares about $80 \%$ of the genetic sequence with SARS-CoV, which they also have the same cell entry receptor (23). Based on studies was performed by Zhao et al., it is demonstrated that $83 \%$ of ACE2-expressing cells were alveolar epithelial type II cells (AECII), suggesting that these cells can serve as a reservoir for viral invasion (24). Extrapulmonary sites such as the heart (25), kidney (26), endothelium (27), intestine (28), and liver (29) also expressed the ACE2 receptor. During recent studies, it is revealed that SARS-CoV-2 can bind to the cholangiocyte ACE2 receptors leading to cholangiocyte dysfunction and, through the induction of a systematic inflammatory response, causes liver injury (30). Also, Through liver biopsy assessing of the deceased case of COVID19, moderate microvesicular steatosis, a common finding in sepsis (31), and mild lobular and portal activity were observed, which confirming that this injury could occur; as a result SARSCoV-2 infection (32). In another theory, it is postulated that viral-induced cytotoxic T cells and imbalanced innate immune system lead to collateral liver damage, indicating the association between abnormal liver markers and COVID-19 disease severity $(33,34)$.

Recent studies on SARS clinical features have revealed that the liver enzyme abnormalities are common but not as the prominent feature of this illness (35). Through the recent pandemic of SARS-CoV-2, liver dysfunction in many varieties has been reported in many cases. In this 
medRxiv preprint doi: https://doi.org/10.1101/2020.05.20.20108357; this version posted May 23, 2020. The copyright holder for this preprint (which was not certified by peer review) is the author/funder, who has granted medRxiv a license to display the preprint in perpetuity.

All rights reserved. No reuse allowed without permission.

systematic review and meta-analyses, we aimed to evaluate the prognoses of liver damage. Liver test abnormality at the admission time can be used as a predictor for the severity of the disease (36). In this case, it is assumed that enhanced end-expiratory pressure by increasing right atrial pressure lead to hepatic congestion and blocked venous return. So many patients admitted to the hospital are with liver abnormalities in the absence of mechanical ventilation (33).

Acute liver injury caused by SARS-CoV-2 is more common in patients with poor prognosis who had significantly higher risks of developing severe pneumonia, and Male elderly COVID19 patients with diabetes and lymphopenia. In the early stages, it could enhance the mortality risk in COVID-19 patients. Also, it is reported that hepatic functional indexes of two-third COVID-19 patients remain poor in two weeks after discharge as the consequence of Compassionate drug usage during hospitalization due to lacking specific drug for SARS-CoV$2(37,38)$.

In the current study, trough analyses, results showed significantly higher liver toxicity in sever patients than non-sever patients. The liver toxicity (hepatotoxicity) is a common adverse event that could occur during clinical practice because of the leading systemic toxicity of drugs and chemicals (39). Many drugs used for COVID-19 patients also could damage the liver and among them lopinavir/ritonavir associated with seven times higher odds of liver injury, which have been reported to cause liver damage and affect liver tests $(36,40)$. Other drugs that have been used for the treatment of COVID-19 patients, such as antibiotics, antivirals, and steroids, could potentially damage the liver, but still not being evident (41). However, for hospitalized patients, more attention should be paid to drug-induced liver damage. All to gather Liver enzymes elevation could be due to drugs used for treatment, sepsis, and shock (36).

In this systematic and meta-analyses review, we observed a higher amount of ALT, AST, LDH, D-Dimer, CRP, and total Bilirubin (TBIL) with slightly lower albumin in sever group compared to non-sever groups.

Based on previous studies on the ACE2 receptor, it is reported that slight amounts of these receptors were expressed in human hepatocyte $(27,42)$, indicating the non-significant influence of liver function by SARS-CoV-2 infection in non-sever and mild cases $(43,44)$.

Recent studies have reported the incidence of liver damage in severe cases of COVID-19 with mostly higher ALT, AST, LDH, CRP, D-dimer, and total bilirubin amount and lower albumin (36, 37, 43-45). Also, it has been mentioned that D-dimer, C-reactive protein, and AST higher levels were associated with COVID-19 severity (44). Moreover, through a study on deceased cases of COVID-19 with liver abnormalities, it is reported that in patients with severe complications, ALT, AST, and TBIL were higher than the standard limit. Furthermore, total albumin was also reported lower than the limited upper unit (46). In addition, in other studies, lower albumin levels in severe cases also have been reported $(44,47)$. Hypoalbuminemia could occur as a result of inadequate nutrition intake and overconsumption during hospitalization (43).

Based on the result of this study, patients who have the severe condition are 5.54, 4.22, 4.96, 4.13 and 4.34 times more likely to have elevated CRP, ALT, AST, LDH, D-dimer enzymes retrospectively. However, the chance of developing liver toxicity as a complication of COVID19 was 1.76 times more in severe patients. Also, in a similar study, elevated serum levels of AST, ALT, and total Bilirubin, and lower levels of Albumin were observed in severe cases. 
medRxiv preprint doi: https://doi.org/10.1101/2020.05.20.20108357; this version posted May 23, 2020. The copyright holder for this preprint (which was not certified by peer review) is the author/funder, who has granted medRxiv a license to display the preprint in perpetuity. All rights reserved. No reuse allowed without permission.

Their meta-analyses for AST (95\% CI $=5.97$ to $11.71, \mathrm{I}^{2}=73.4 \%$ ), ALT (95\% CI $=4.77$ to 9.93, $\mathrm{I}^{2}=57.2 \%$ ), TBIL (95\% CI $=1.24$ to $3.36, \mathrm{I}^{2}=68.8 \%$ ), and Albumin (95\% $\mathrm{CI}=-6.20$ to $\left.-2.28, \mathrm{I}^{2}=95.7 \%\right)(21)$ results were difference with us where AST $\left(95 \% \mathrm{Cl}, 14-23, \mathrm{I}^{2}=94.03 \%\right)$, ALT $\left(95 \% \mathrm{Cl}, 13-21, \mathrm{I}^{2}=97.47 \%\right)$, and TBIL (95\% Cl, 7-17, $\left.\mathrm{I}^{2}=66.67 \%\right)$, ( $95 \% \mathrm{Cl}, 0-88$, $\mathrm{I}^{2}=0 \%$ ) in severe cases accompanied with better results except of Albumin due to higher included studies.

In another systematic review and meta-analyses survey on liver function during COVID-19, it is reported that elevated AST(95\% CI 13.6 to 16.5) and ALT(95\% CI 13.6 to 16.4) were seen in $15 \%$ of patients; also, increases in TBIL was seen in $16.7 \%$ (95\% CI 15.0 to 18.5 ) of patients. Theses upper than normal limit increases were attributed to drug or viral induced hepatic injury. Drug-induced hepatotoxicity also was reported with Remdesivir and Favipiravir. Notably, Lopinavir/ritonavir liver injury had not been evident in COVID-19 patients, and liver injury with Chloroquine and Hydroxychloroquine reported rare. They not specifically compared these increases in non-severe than severe patients (48).

Some studies also reported that LDH was higher in COVID-19 patients with severe pneumonia. LDH is an essential element in glucose metabolism and expressed widely through organ body tissues, especially in myocardial and liver cells. LDH would release within cells upon the cytoplasmic membrane damage (34). Based on previous studies on SARS and MERS, the elevated levels of LDH also were reported. So it can be concluded that LDH independently could act as a risk factor with poor clinical outcomes and raised the alarm for further analyses $(45,49)$. The higher levels of LDH maybe is due to the broad expression of ACE2 receptors in cardiac blood vessels $(27,50)$. In another theory, the increased amount of LDH was attributed to myositis, which resulted from virus infection (33). Moreover, its amounts would be increased as a cause of hepatocyte injuries because of the coexisting of ACE2 receptors in hepatocytes. So it's lightening this fact that liver and cardiac damage could occur as a direct effect of SARS-Cov-2 on targeted organ damage (34). Thus elevated LDH enzyme in sever cases might occur as a consequence of directed hepatic or extrahepatic damage.

Like SARS-CoV, SARS-CoV-2 could affect lymphocytes, especially T lymphocytes (34). Patients with damaged $\mathrm{T}$ cells are more vulnerable to infections and their risk increase in patients with severe illness. The CRP in sever patients had higher levels than non-sever, and the CRP level above $100 \mathrm{mg} / \mathrm{dl}$ could be an alarm for bacterial infection. So higher CRP might indicate the risk of other infections (mostly opportunistic infections), which could affect the liver or lead to hepatitis, and act as a prognostic factor (51-54). On the other hand, cytokine factors that were marked by higher concentrations of CRP, ESR, ferritin, and hs-CRP are associated with the severity of COVID-19. As a result, higher amounts of cytokine factors in blood serum might suggest a pro-inflammatory factor storm (55).

Another severe complication that occurred in COVID-19 patients is sepsis, and it could be with some clinical and labratorical manifestations. Through labratorical analyses, hyperbilirubinemia, acidosis, high lactate, coagulopathy, and thrombocytopenia were mostly seen in COVID-19 patients in ICU $(56,57)$. Also, as mentioned above, sepsis is one of the liver injury causes during infection with SARS-Cov-2.

Trough abnormal laboratory findings in severely affected patients, aberrant coagulation has been reported (58). Also, based on recent studies, it is revealed that COVID-19 is associated 
with the classical syndrome named disseminated intravascular coagulation (59) and the subsequent consumption coagulopathy (60). The D-dimer is a fibrin degradation product which highly increases during DIC (61). Besides, The elevation in D-dimer levels could occur as a result of cirrhosis and also are increased gradually as the degree of liver dysfunction increases in severity $(62,63)$. All to gather higher levels of D-dimer with hepatic or extrahepatic origin could be act as a prognostic factor for COVID-19.

Nevertheless, In a study, it is reported that liver indexes such as ALT, AST, TBIL, ALP, ALB, GLB, INR, LDH, and CRP hadn't independently any association with the severity of COVID19 (43).

All to gather in this systematic review and meta-analyses, abnormal liver markers where different in sever group than the non-sever group. Higher ALT, AST, LDH, CRP, D-dimer, and total bilirubin amount and lower albumin altogether but not independently could be a prognostic factor for COVID-19 patients.

The present study has some limitations. All of the studies have been conducted in China, whereas covid19 is pandemic now. Interpretation of our meta-analysis findings might be limited by the small sample size. limitations on the information provided in studies constrained subgroup analysis.

\section{Conclusion}

The liver because of ACE2 expression in this site is prone to injury as a result of infection with SARS-CoV-2. Through our meta-analyzes elevation of some liver, markers were higher in sever group when compared to the non-sever group. Also, it is notable that Albumin was significantly reduced in severe compared to non-sever patients. Besides some medications were used to treatment of COVID-19 patients could be toxic for the liver. Through results, we observed significantly considerable numbers of drug-induced liver toxicity in sever group than the non-sever group. All to gather in the current study, we assumed that abnormal liver markers could act as a prognostic factor for a better survey of COVID-19.

\section{Acknowledgment}

The authors would like to thank the Student Research Committee of Mazandaran University of Medical Sciences for supporting this project. This study was approved in the Ethical Review Committee of the Mazandaran University of Medical Science with ethical code IR.MAZUMS.REC.1399.049.

\section{Conflict of interest}

The authors have no conflicts of interest to declare

\section{References:}


medRxiv preprint doi: https://doi.org/10.1101/2020.05.20.20108357; this version posted May 23, 2020. The copyright holder for this preprint (which was not certified by peer review) is the author/funder, who has granted medRxiv a license to display the preprint in perpetuity.

All rights reserved. No reuse allowed without permission.

1. Chan JF-W, Yuan S, Kok K-H, To KK-W, Chu H, Yang J, et al. A familial cluster of pneumonia associated with the 2019 novel coronavirus indicating person-to-person transmission: a study of a family cluster. 2020;395(10223):514-23.

2. Organization WH. Coronavirus disease (COVID-2019) situation reports. 2020.

3. Mahase EJB. China coronavirus: WHO declares international emergency as death toll exceeds 200. 2020;368:m408.

4. Li W, Moore MJ, Vasilieva N, Sui J, Wong SK, Berne MA, et al. Angiotensin-converting enzyme 2 is a functional receptor for the SARS coronavirus. 2003;426(6965):450-4.

5. Lu H, Ai J, Shen Y, Li Y, Li T, Zhou X, et al. A descriptive study of the impact of diseases control and prevention on the epidemics dynamics and clinical features of SARS-CoV-2 outbreak in Shanghai, lessons learned for metropolis epidemics prevention. medRxiv. 2020.

6. Yeo C, Kaushal S, Yeo DJTLG, Hepatology. Enteric involvement of coronaviruses: is faecaloral transmission of SARS-CoV-2 possible? 2020;5(4):335-7.

7. Yang $X, Y u Y, X u J$ J, Shu H, Liu H, Wu Y, et al. Clinical course and outcomes of critically ill patients with SARS-CoV-2 pneumonia in Wuhan, China: a single-centered, retrospective, observational study. 2020.

8. $\quad$ Singhal TJTIJoP. A review of coronavirus disease-2019 (COVID-19). 2020:1-6.

9. Chen N, Zhou M, Dong X, Qu J, Gong F, Han Y, et al. Epidemiological and clinical characteristics of 99 cases of 2019 novel coronavirus pneumonia in Wuhan, China: a descriptive study. 2020;395(10223):507-13.

10. Zhao Z, Xie J, Yin M, Yang Y, He H, Jin T, et al. Clinical and Laboratory Profiles of 75 Hospitalized Patients with Novel Coronavirus Disease 2019 in Hefei, China. medRxiv. 2020.

11. Huang C, Wang Y, Li X, Ren L, Zhao J, Hu Y, et al. Clinical features of patients infected with 2019 novel coronavirus in Wuhan, China. 2020;395(10223):497-506.

12. Heydari K, Rismantab S, Shamshirian A, Lotfi P, Shadmehri N, Houshmand P, et al. Clinical and Paraclinical Characteristics of COVID-19 patients: A systematic review and meta-analysis. 2020.

13. Zhang C, Shi L, Wang F-SJTLG, Hepatology. Liver injury in COVID-19: management and challenges. 2020.

14. Fu L, Fei J, Xu S, Xiang H-X, Xiang Y, Tan Z-X, et al. Acute liver injury and its association with death risk of patients with COVID-19: a hospital-based prospective case-cohort study. 2020.

15. Xu L, Liu J, Lu M, Yang D, Zheng XJLI. Liver injury during highly pathogenic human coronavirus infections. 2020.

16. Bangash MN, Patel J, Parekh DJTLG, Hepatology. COVID-19 and the liver: little cause for concern. 2020.

17. Brinkløv S, Elemans C, Ratcliffe J, Fenton MJCB. Elijah Trefts, Maureen Gannon, and David H. Wasserman. 2017;27:R1141-R55.

18. Asrani SK, Devarbhavi H, Eaton J, Kamath PSJJoh. Burden of liver diseases in the world. 2019;70(1):151-71.

19. Mokdad AA, Lopez AD, Shahraz S, Lozano R, Mokdad AH, Stanaway J, et al. Liver cirrhosis mortality in 187 countries between 1980 and 2010: a systematic analysis. 2014;12(1):145.

20. Omrani-Nava V, Maleki I, Ahmadi A, Moosazadeh M, Hedayatizadeh-Omran A, Roozbeh F, et al. Evaluation of Hepatic Enzymes Changes and Association with Prognosis in COVID-19 Patients. Hepatitis Monthly. 2020;20(4).

21. Parohan M, Yaghoubi S, Seraj A. Liver injury is associated with severe Coronavirus disease 2019 (COVID -19) infection: a systematic review and meta-analysis of retrospective studies. medRxiv. 2020.

22. Ramesh N, Siddaiah A, Joseph B. Tackling corona virus disease 2019 (COVID 19) in workplaces. Indian Journal of Occupational and Environmental Medicine. 2020;24(1):16.

23. Xu X, Chen P, Wang J, Feng J, Zhou H, Li X, et al. Evolution of the novel coronavirus from the ongoing Wuhan outbreak and modeling of its spike protein for risk of human transmission. Science China Life Sciences. 2020;63(3):457-60. 
medRxiv preprint doi: https://doi.org/10.1101/2020.05.20.20108357; this version posted May 23, 2020. The copyright holder for this preprint (which was not certified by peer review) is the author/funder, who has granted medRxiv a license to display the preprint in perpetuity.

All rights reserved. No reuse allowed without permission.

24. Zhao $Y$, Zhao Z, Wang $Y$, Zhou $Y$, Ma Y, Zuo W. Single-cell RNA expression profiling of ACE2, thereceptor of SARS-CoV-2. bioRxiv. 2020.

25. Crackower MA, Sarao R, Oudit GY, Yagil C, Kozieradzki I, Scanga SE, et al. Angiotensinconverting enzyme 2 is an essential regulator of heart function. Nature. 2002;417(6891):822-8. 26. Danilczyk U, Sarao R, Remy C, Benabbas C, Stange G, Richter A, et al. Essential role for collectrin in renal amino acid transport. Nature. 2006;444(7122):1088-91.

27. Hamming I, Timens W, Bulthuis M, Lely A, Navis G, van Goor H. Tissue distribution of ACE2 protein, the functional receptor for SARS coronavirus. A first step in understanding SARS pathogenesis. The Journal of Pathology: A Journal of the Pathological Society of Great Britain and Ireland. 2004;203(2):631-7.

28. Vuille-dit-Bille RN, Camargo SM, Emmenegger L, Sasse T, Kummer E, Jando J, et al. Human intestine luminal ACE2 and amino acid transporter expression increased by ACE-inhibitors. Amino acids. 2015;47(4):693-705.

29. Zhang C, Shi L, Wang F-S. Liver injury in COVID-19: management and challenges. The Lancet Gastroenterology \& Hepatology. 2020.

30. Chai X, Hu L, Zhang Y, Han W, Lu Z, Ke A, et al. Specific ACE2 expression in cholangiocytes may cause liver damage after 2019-nCoV infection. bioRxiv. 2020.

31. Koskinas J, Gomatos IP, Tiniakos DG, Memos N, Boutsikou M, Garatzioti A, et al. Liver histology in ICU patients dying from sepsis: a clinico-pathological study. World journal of gastroenterology: WJG. 2008;14(9):1389.

32. Xu Z, Shi L, Wang Y. Pathological findings of COVID-19 associated with acute respiratory distress syndrome [published online ahead of print February 18, 2020]. The Lancet Respiratory medicine.

33. Bangash MN, Patel J, Parekh D. COVID-19 and the liver: little cause for concern. The Lancet Gastroenterology \& Hepatology. 2020.

34. Han Y, Zhang H, Mu S, Wei W, Jin C, Xue Y, et al. Lactate dehydrogenase, a Risk Factor of Severe COVID-19 Patients. medRxiv. 2020.

35. Humar A, McGilvray I, Phillips MJ, Levy GA. Severe acute respiratory syndrome and the liver. Hepatology (Baltimore, Md). 2004;39(2):291-4.

36. Cai Q, Huang D, Yu H, Zhu Z, Xia Z, Su Y, et al. Characteristics of Liver Tests in COVID-19 Patients. Journal of Hepatology. 2020.

37. Fu L, Fei J, Xu S, Xiang H-X, Xiang Y, Tan Z-X, et al. Acute liver injury and its association with death risk of patients with COVID-19: a hospital-based prospective case-cohort study. medRxiv. 2020.

38. Kalil AC. Treating COVID-19-off-label drug use, compassionate use, and randomized clinical trials during pandemics. JAMA. 2020.

39. Ramirez T, Strigun A, Verlohner A, Huener H-A, Peter E, Herold M, et al. Prediction of liver toxicity and mode of action using metabolomics in vitro in HepG2 cells. Archives of toxicology. 2018;92(2):893-906.

40. Meraviglia P, Schiavini M, Castagna A, Vigano P, Bini T, Landonio S, et al. Lopinavir/ritonavir treatment in HIV antiretroviral-experienced patients: evaluation of risk factors for liver enzyme elevation. HIV medicine. 2004;5(5):334-43.

41. Yang $X, Y u Y, X u$ J, Shu H, Liu H, Wu Y, et al. Clinical course and outcomes of critically ill patients with SARS-CoV-2 pneumonia in Wuhan, China: a single-centered, retrospective, observational study. The Lancet Respiratory Medicine. 2020.

42. Grace JA, Herath CB, Mak KY, Burrell LM, Angus PW. Update on new aspects of the reninangiotensin system in liver disease: clinical implications and new therapeutic options. Clinical science. 2012;123(4):225-39.

43. Zhang $\mathrm{Y}$, Zheng L, Liu L, Zhao M, Xiao J, Zhao Q. Liver impairment in COVID-19 patients: a retrospective analysis of 115 cases from a single center in Wuhan city, China. Liver International. 2020. 
medRxiv preprint doi: https://doi.org/10.1101/2020.05.20.20108357; this version posted May 23, 2020. The copyright holder for this preprint (which was not certified by peer review) is the author/funder, who has granted medRxiv a license to display the preprint in perpetuity.

All rights reserved. No reuse allowed without permission.

44. Feng Y, Ling Y, Bai T, Xie Y, Huang J, Li J, et al. COVID-19 with Different Severity: A Multicenter Study of Clinical Features. American Journal of Respiratory and Critical Care Medicine. 2020(ja).

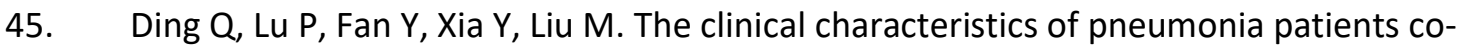
infected with 2019 novel coronavirus and influenza virus in Wuhan, China. Journal of Medical Virology. 2020.

46. Yang F, Shi S, Zhu J, Shi J, Dai K, Chen X. Analysis of 92 deceased patients with COVID-19. Journal of Medical Virology. 2020.

47. Gong J, Ou J, Qiu X, Jie Y, Chen Y, Yuan L, et al. A Tool to Early Predict Severe 2019-Novel Coronavirus Pneumonia (COVID-19): A Multicenter Study using the Risk Nomogram in Wuhan and Guangdong, China. medRxiv. 2020.

48. Sultan S, Altayar O, Siddique SM, Davitkov P, Feuerstein JD, Lim JK, et al. AGA Institute Rapid Review of the GI and Liver Manifestations of COVID-19, Meta-Analysis of International Data, and Recommendations for the Consultative Management of Patients with COVID-19.

49. Zhang R, Ouyang H, Fu L, Wang S, Han J, Huang K, et al. CT features of SARS-CoV-2 pneumonia according to clinical presentation: a retrospective analysis of 120 consecutive patients from Wuhan city. European radiology. 2020:1-10.

50. Jiang $F$, Yang J, Zhang $Y$, Dong $M$, Wang S, Zhang Q, et al. Angiotensin-converting enzyme 2 and angiotensin 1-7: novel therapeutic targets. Nat Rev Cardiol. 2014;11(7):413.

51. Gille-Johnson P, Hansson KE, Gårdlund B. Clinical and laboratory variables identifying bacterial infection and bacteraemia in the emergency department. Scandinavian journal of infectious diseases. 2012;44(10):745-52.

52. Cals JW, Schot MJ, de Jong SA, Dinant G-J, Hopstaken RM. Point-of-care C-reactive protein testing and antibiotic prescribing for respiratory tract infections: a randomized controlled trial. The Annals of Family Medicine. 2010;8(2):124-33.

53. Khadijah K, Ferica K, Katu S, Halim R, Mubin A, editors. Analysis of the association opportunistic infections with c-reactive protein focus toxoplasma, cytomegalovirus, rubella, and hepatitis in human immunodeficiency virus. IOP Conference Series: Earth and Environmental Science; 2018: IOP Publishing.

54. Bin L, Yangzhong W, Yuanyuan Z, Huibo S, Fanjun Z, Zhishui C. Successful Treatment of Severe COVID-19 Pneumonia in a Liver Transplant Recipient. American Journal of Transplantation. 2020.

55. Fu S, Fu X, Song Y, Li M, Pan P-h, Tang T, et al. Virologic and clinical characteristics for prognosis of severe COVID-19: a retrospective observational study in Wuhan, China. medRxiv. 2020. 56. Seymour CW, Kennedy JN, Wang S, Chang C-CH, Elliott CF, Xu Z, et al. Derivation, validation, and potential treatment implications of novel clinical phenotypes for sepsis. Jama.

2019;321(20):2003-17.

57. Cascella M, Rajnik M, Cuomo A, Dulebohn SC, Di Napoli R. Features, evaluation and treatment coronavirus (COVID-19). Statpearls [internet]: StatPearls Publishing; 2020.

58. Zhang G, Hu C, Luo L, Fang F, Chen Y, Li J, et al. Clinical features and short-term outcomes of 221 patients with COVID-19 in Wuhan, China. Journal of Clinical Virology. 2020:104364.

59. Lippi G, Simundic A-M, Plebani M. Potential preanalytical and analytical vulnerabilities in the laboratory diagnosis of coronavirus disease 2019 (COVID-19). Clinical Chemistry and Laboratory Medicine (CCLM). 2020.

60. Marietta M, Ageno W, Artoni A, De Candia E, Gresele P, Marchetti M, et al. COVID-19 and haemostasis: a position paper from Italian Society on Thrombosis and Haemostasis (SISET). Blood transfusion= Trasfusione del sangue. 2020.

61. Johnson ED, Schell JC, Rodgers GM. The D-dimer assay. American journal of hematology. 2019;94(7):833-9. 
medRxiv preprint doi: https://doi.org/10.1101/2020.05.20.20108357; this version posted May 23, 2020. The copyright holder for this preprint (which was not certified by peer review) is the author/funder, who has granted medRxiv a license to display the preprint in perpetuity.

All rights reserved. No reuse allowed without permission.

62. Gram J, Duscha H, Zurborn K, Bruhn H. Increased levels of fibrinolysis reaction products (Ddimer) in patients with decompensated alcoholic liver cirrhosis. Scandinavian journal of gastroenterology. 1991;26(11):1173-8.

63. Li Y, Qi X, Li H, Dai J, Deng H, Li J, et al. D-dimer level for predicting the in-hospital mortality in liver cirrhosis: A retrospective study. Experimental and therapeutic medicine. 2017;13(1):285-9. 64. Guan W-j, Ni Z-y, Hu Y, Liang W-h, Ou C-q, He J-x, et al. Clinical characteristics of coronavirus disease 2019 in China. New England Journal of Medicine. 2020.

65. Fu L, Fei J, Xiang H-X, Xiang Y, Tan Z-X, Li M-D, et al. Influence factors of death risk among COVID-19 patients in Wuhan, China: a hospital-based case-cohort study. medRxiv. 2020.

66. Fu H, Xu H, Zhang N, Xu H, Li Z, Chen H, et al. Association between Clinical, Laboratory and CT Characteristics and RT-PCR Results in the Follow-up of COVID-19 patients. medRxiv. 2020.

67. Zhou F, Yu T, Du R, Fan G, Liu Y, Liu Z, et al. Clinical course and risk factors for mortality of adult inpatients with COVID-19 in Wuhan, China: a retrospective cohort study. The Lancet. 2020.

68. Chen H, Guo J, Wang C, Luo F, Yu X, Zhang W, et al. Clinical characteristics and intrauterine vertical transmission potential of COVID-19 infection in nine pregnant women: a retrospective review of medical records. The Lancet. 2020;395(10226):809-15.

69. Chen X, Zheng F, Qing Y, Ding S, Yang D, Lei C, et al. Epidemiological and clinical features of 291 cases with coronavirus disease 2019 in areas adjacent to Hubei, China: a double-center observational study. medRxiv. 2020.

70. Chen T, Wu D, Chen H, Yan W, Yang D, Chen G, et al. Clinical characteristics of 113 deceased patients with coronavirus disease 2019: retrospective study. BMJ. 2020;368.

71. Chen N, Zhou M, Dong X, Qu J, Gong F, Han Y, et al. Epidemiological and clinical characteristics of 99 cases of 2019 novel coronavirus pneumonia in Wuhan, China: a descriptive study. The Lancet. 2020;395(10223):507-13.

72. Chen J, Qi T, Liu L, Ling Y, Qian Z, Li T, et al. Clinical progression of patients with COVID-19 in Shanghai, China. The Journal of infection. 2020. Epub 2020/03/17. doi: 10.1016/j.jinf.2020.03.004. PubMed PMID: 32171869; PubMed Central PMCID: PMCPMC7102530.

73. Ai J, Chen J, Wang Y, Liu X, Fan W, Qu G, et al. The cross-sectional study of hospitalized coronavirus disease 2019 patients in Xiangyang, Hubei province. medRxiv. 2020.

74. Xu S, Fu L, Fei J, Xiang H-X, Xiang Y, Tan Z-X, et al. Acute kidney injury at early stage as a negative prognostic indicator of patients with COVID-19: a hospital-based retrospective analysis. medRxiv. 2020.

75. Zhang G, Zhang J, Wang B, Zhu X, Wang Q, Qiu S. Analysis of clinical characteristics and laboratory findings of 95 cases of 2019 novel coronavirus pneumonia in Wuhan, China: a retrospective analysis. Respiratory Research. 2020;21(1):1-10.

76. Zhao W, Yu S, Zha X, Wang N, Pang Q, Li T, et al. Clinical characteristics and durations of hospitalized patients with COVID-19 in Beijing: a retrospective cohort study. medRxiv. 2020.

77. Tian S, Chang Z, Wang Y, Wu M, Zhang W, Zhou G, et al. Clinical characteristics and reasons of different duration from onset to release from quarantine for patients with COVID-19 Outside Hubei province, China. medRxiv. 2020.

78. Wang L, He W, Yu X, Hu D, Bao M, Liu H, et al. Coronavirus Disease 2019 in elderly patients: characteristics and prognostic factors based on 4-week follow-up. The Journal of infection. 2020. Epub 2020/04/03. doi: 10.1016/j.jinf.2020.03.019. PubMed PMID: 32240670.

79. Wang W, He J, Wu S. The definition and risks of Cytokine Release Syndrome-Like in 11 COVID-19-Infected Pneumonia critically ill patients: Disease Characteristics and Retrospective Analysis. Medrxiv. 2020.

80. Huang Y, Zhou H, Yang R, Xu Y, Feng X, Gong P. Clinical characteristics of 36 non-survivors with COVID-19 in Wuhan, China. medRxiv. 2020.

81. Zhang B, Zhou X, Qiu Y, Feng F, Feng J, Jia Y, et al. Clinical characteristics of 82 death cases with COVID-19. medRxiv. 2020. 
medRxiv preprint doi: https://doi.org/10.1101/2020.05.20.20108357; this version posted May 23, 2020. The copyright holder for this preprint (which was not certified by peer review) is the author/funder, who has granted medRxiv a license to display the preprint in perpetuity.

All rights reserved. No reuse allowed without permission.

82. Zhang Jj, Dong X, Cao YY, Yuan Yd, Yang Yb, Yan Yq, et al. Clinical characteristics of 140 patients infected by SARS-CoV-2 in Wuhan, China. Allergy. 2020.

83. Zheng F, Liao C, Fan Q-h, Chen H-b, Zhao X-g, Xie Z-g, et al. Clinical Characteristics of Children with Coronavirus Disease 2019 in Hubei, China. Current Medical Science. 2020:1-6.

84. Zhang L, Zhu F, Xie L, Wang C, Wang J, Chen R, et al. Clinical characteristics of COVID-19infected cancer patients: A retrospective case study in three hospitals within Wuhan, China. Annals of Oncology. 2020.

85. Zheng $Y$, Huang Z, Ying G, Zhang X, Ye W, Hu Z, et al. Comparative study of the lymphocyte change between COVID-19 and non-COVID-19 pneumonia cases suggesting uncontrolled inflammation might not be the main reason of tissue injury. medRxiv. 2020.

86. Zhao D, Yao F, Wang L, Zheng L, Gao Y, Ye J, et al. A comparative study on the clinical features of COVID-19 pneumonia to other pneumonias. Clinical Infectious Diseases. 2020.

87. Tang X, Du R, Wang R, Cao T, Guan L, Yang C, et al. Comparison of Hospitalized Patients with Acute Respiratory Distress Syndrome Caused by COVID-19 and H1N1. Chest. 2020.

88. Huang H, Cai S, Li Y, Li Y, Fan Y, Li L, et al. Prognostic factors for COVID-19 pneumonia progression to severe symptom based on the earlier clinical features: a retrospective analysis. medRxiv. 2020.

89. Tang A, Xu W, Chen P, Li G, Liu Y, Liu L. A retrospective study of the clinical characteristics of COVID-19 infection in 26 children. medRxiv. 2020.

90. Lei L, Jian-Ya G, Hu W, Zhang X, Gua L, Liu C. Clinical characteristics of 51 patients discharged from hospital with COVID-19 in Chongqing, China. MedRxiv. 2020.

91. Liao J, Fan S, Chen J, Wu J, Xu S, Guo Y, et al. Epidemiological and clinical characteristics of COVID-19 in adolescents and young adults. The Innovation. 2020.

92. Nie S, Zhao X, Zhao K, Zhang Z, Zhang Z, Zhang Z. Metabolic disturbances and inflammatory dysfunction predict severity of coronavirus disease 2019 (COVID-19): a retrospective study. medRxiv. 2020.

93. Qian G-Q, Yang N-B, Ding F, Ma AHY, Wang Z-Y, Shen Y-F, et al. Epidemiologic and Clinical Characteristics of 91 Hospitalized Patients with COVID-19 in Zhejiang, China: A retrospective, multicentre case series. QJM: An International Journal of Medicine. 2020.

94. Qiu C, Xiao Q, Liao X, Deng Z, Liu H, Shu Y, et al. Transmission and clinical characteristics of coronavirus disease 2019 in 104 outside-Wuhan patients, China. medRxiv. 2020.

95. Shi Q, Zhao K, Yu J, Feng J, Zhao K, Zhang X, et al. Clinical characteristics of 101 non-surviving hospitalized patients with COVID-19: A single center, retrospective study. medRxiv. 2020.

96. Wan S, Xiang Y, Fang W, Zheng Y, Li B, Hu Y, et al. Clinical Features and Treatment of COVID19 Patients in Northeast Chongqing. Journal of Medical Virology. 2020.

97. Wang Y, Liu Y, Liu L, Wang X, Luo N, Li L. Clinical Outcomes in 55 Patients With Severe Acute Respiratory Syndrome Coronavirus 2 Who Were Asymptomatic at Hospital Admission in Shenzhen, China. The Journal of Infectious Diseases. 2020.

98. Wang Y, Zhou Y, Yang Z, Xia D, Geng S. Clinical Characteristics of Patients with Severe Pneumonia Caused by the 2019 Novel Coronavirus in Wuhan, China. medRxiv. 2020.

99. Wu J, Liu J, Zhao X, Liu C, Wang W, Wang D, et al. Clinical Characteristics of Imported Cases of Coronavirus Disease 2019 (COVID-19) in Jiangsu Province: A Multicenter Descriptive Study. Clinical Infectious Diseases. 2020.

100. Xie H, Zhao J, Lian N, Lin S, Xie Q, Zhuo H. Clinical characteristics of Non-ICU hospitalized patients with coronavirus disease 2019 and liver injury : A Retrospective study. Liver international. 2020.

101. Xu X-W, Wu X-X, Jiang X-G, Xu K-J, Ying L-J, Ma C-L, et al. Clinical findings in a group of patients infected with the 2019 novel coronavirus (SARS-Cov-2) outside of Wuhan, China: retrospective case series. Bmj. 2020;368. 
medRxiv preprint doi: https://doi.org/10.1101/2020.05.20.20108357; this version posted May 23, 2020. The copyright holder for this preprint (which was not certified by peer review) is the author/funder, who has granted medRxiv a license to display the preprint in perpetuity.

All rights reserved. No reuse allowed without permission.

102. Xu Y, Xu Z, Liu X, Cai L, Zheng H, Huang $Y$, et al. Clinical findings in critical ill patients infected with SARS-Cov-2 in Guangdong Province, China: a multi-center, retrospective, observational study. medRxiv. 2020.

103. Zhou F, Yu X, Tong X, Zhang R. Clinical features and outcomes of 197 adult discharged patients with COIVD-19 in Yichang, Hubei. medRxiv. 2020.

104. Cai Q, Huang D, Yu H, Zhu Z, Xia Z, Su Y, et al. Characteristics of Liver Tests in COVID-19 Patients. J Hepatol. 2020. Epub 2020/04/17. doi: 10.1016/j.jhep.2020.04.006. PubMed PMID: 32298767.

105. Fan Z, Chen L, Li J, Cheng X, Jingmao Y, Tian C, et al. Clinical Features of COVID-19-Related Liver Damage. Clin Gastroenterol Hepatol. 2020. Epub 2020/04/14. doi: 10.1016/j.cgh.2020.04.002. PubMed PMID: 32283325.

106. Feng Z, Li J, Yao S, Yu Q, Zhou W, Mao X, et al. The Use of Adjuvant Therapy in Preventing Progression to Severe Pneumonia in Patients with Coronavirus Disease 2019: A Multicenter Data Analysis. medRxiv. 2020.

107. Ji D, Zhang D, Xu J, Chen Z, Yang T, Zhao P, et al. Prediction for Progression Risk in Patients with COVID-19 Pneumonia: the CALL Score. Clinical Infectious Diseases. 2020.

108. Pan L, Mu M, Yang P, Sun Y, Wang R, Yan J, et al. Clinical characteristics of COVID-19 patients with digestive symptoms in Hubei, China: a descriptive, cross-sectional, multicenter study. The American journal of gastroenterology. 2020;115.

109. Ling L, So C, Shum HP, Chan PK, Lai CK, Kandamby DH, et al. Critically ill patients with COVID19 in Hong Kong: a multicentre retrospective observational cohort study. Critical Care and Resuscitation: Journal of the Australasian Academy of Critical Care Medicine. 2020.

110. Han Yn, Feng Zw, Sun Ln, Ren Xx, Wang H, Xue Ym, et al. A comparative-descriptive analysis of clinical characteristics in 2019-coronavirus-infected children and adults. Journal of Medical Virology. 2020.

111. Jiang $\mathrm{X}$, Tao J, $\mathrm{Wu} \mathrm{H}$, Wang $\mathrm{Y}$, Zhao $\mathrm{W}$, Zhou $\mathrm{M}$, et al. Clinical features and management of severe COVID-19: A retrospective study in Wuxi, Jiangsu Province, China. medRxiv. 2020.

112. Chen J, Fan H, Zhang L, Huang B, Zhu M, Zhou Y, et al. Retrospective Analysis of Clinical Features in 101 Death Cases with COVID-19. medRxiv. 2020.

\section{Figure Legend}

Figure 1. PRISMA flowchart for study selection process

Figure 2. Forest plot for odds ratios of laboratory findings

Figure 3. Meta-analysis of prevelance of clinical outcome of patients (A)

Figure 4. Meta-analysis of prevelance of clinical outcome of patients (B)

Figure 5. Meta-analysis of prevalence of laboratory findings of all patients (A)

Figure 6. Meta-analysis of prevalence of laboratory findings of all patients (B)

Figure 7. Meta-analysis of prevalence of comorbidities of all patients (A)

Figure 8. Meta-analysis of prevalence of comorbidities of all patients (B)

Figure 9. Meta-analysis of prevalence of comorbidities of all patients (C)

Figure 10. Meta-analysis of prevalence of comorbidities of all patients (D) 
medRxiv preprint doi: https://doi.org/10.1101/2020.05.20.20108357; this version posted May 23,2020 . The copyright holder for this preprint (which was not certified by peer review) is the author/funder, who has granted medRxiv a license to display the preprint in perpetuity.

All rights reserved. No reuse allowed without permission.

\section{Supporting Information Legend}

Supplementary figure 1. Meta-analysis of prevalence of clinical outcome of non-severe patients.

Supplementary figure 2. Meta-analysis of prevalence of clinical outcome of severe patients. Supplementary figure 3. Meta-analysis of prevalence of laboratory findings of non-severe patients.

Supplementary figure 4. Meta-analysis of prevalence of laboratory findings of severe patients.

Supplementary figure 5. Meta-analysis of prevalence of comorbidities of non-severe patients (A)

Supplementary figure 6. Meta-analysis of prevalence of comorbidities of non-severe patients (B)

Supplementary figure 7. Meta-analysis of prevalence of comorbidities of severe patients (A) Supplementary figure 8. Meta-analysis of prevalence of comorbidities of severe patients (B) Supplementary figure 9. Meta-analysis of prevalence of comorbidities of severe patients (C) 
medRxiv preprint doi: https://doi.org/10.1101/2020.05.20.20108357; this version posted May 23,2020 . The copyright holder for this preprint (which was not certified by peer review) is the author/funder, who has granted medRxiv a license to display the preprint in perpetuity.

All rights reserved. No reuse allowed without permission.

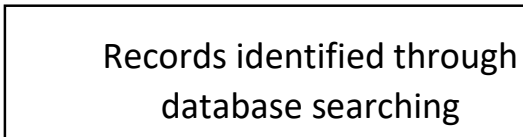

$(n=351)$
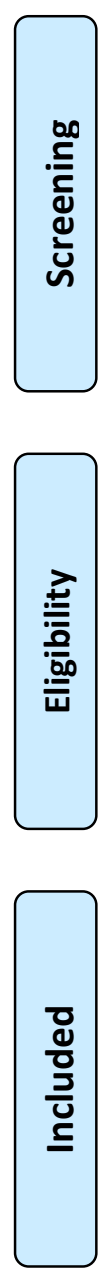

Additional records identified through other sources

$$
(n=643)
$$
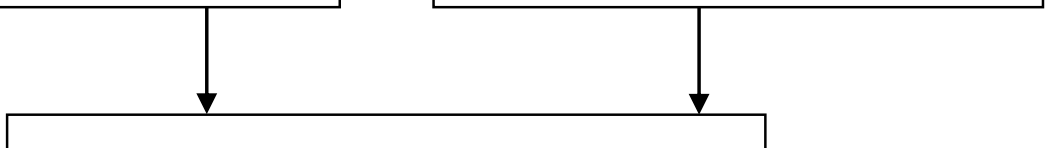

Records after duplicates removed

$$
(n=653)
$$
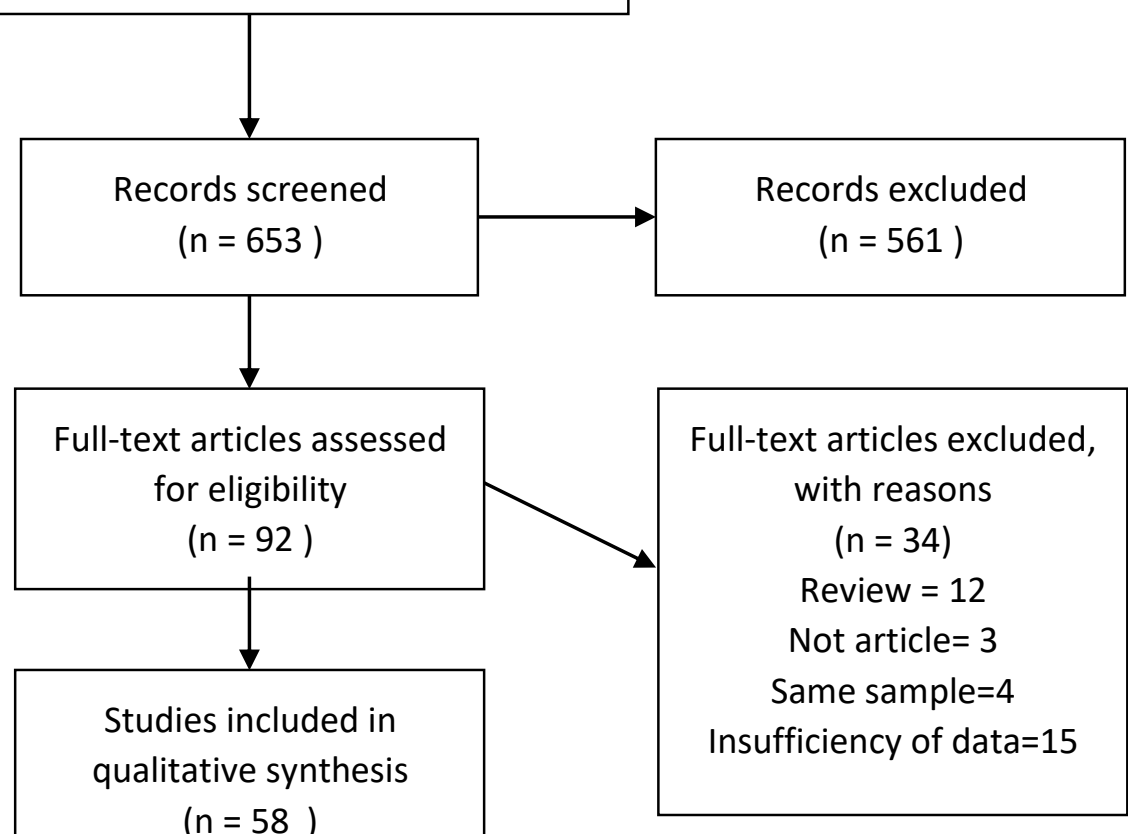

Studies included in quantitative synthesis

(meta-analysis)

$(n=58)$

Figure 1. PRISMA flowchart for study selection process. 
medRxiv preprint doi: https://doi.org/10.1101/2020.05.20.20108357; this version posted May 23, 2020. The copyright holder for this preprint (which was not certified by peer review) is the author/funder, who has granted medRxiv a license to display the preprint in perpetuity.

All rights reserved. No reuse allowed without permission.

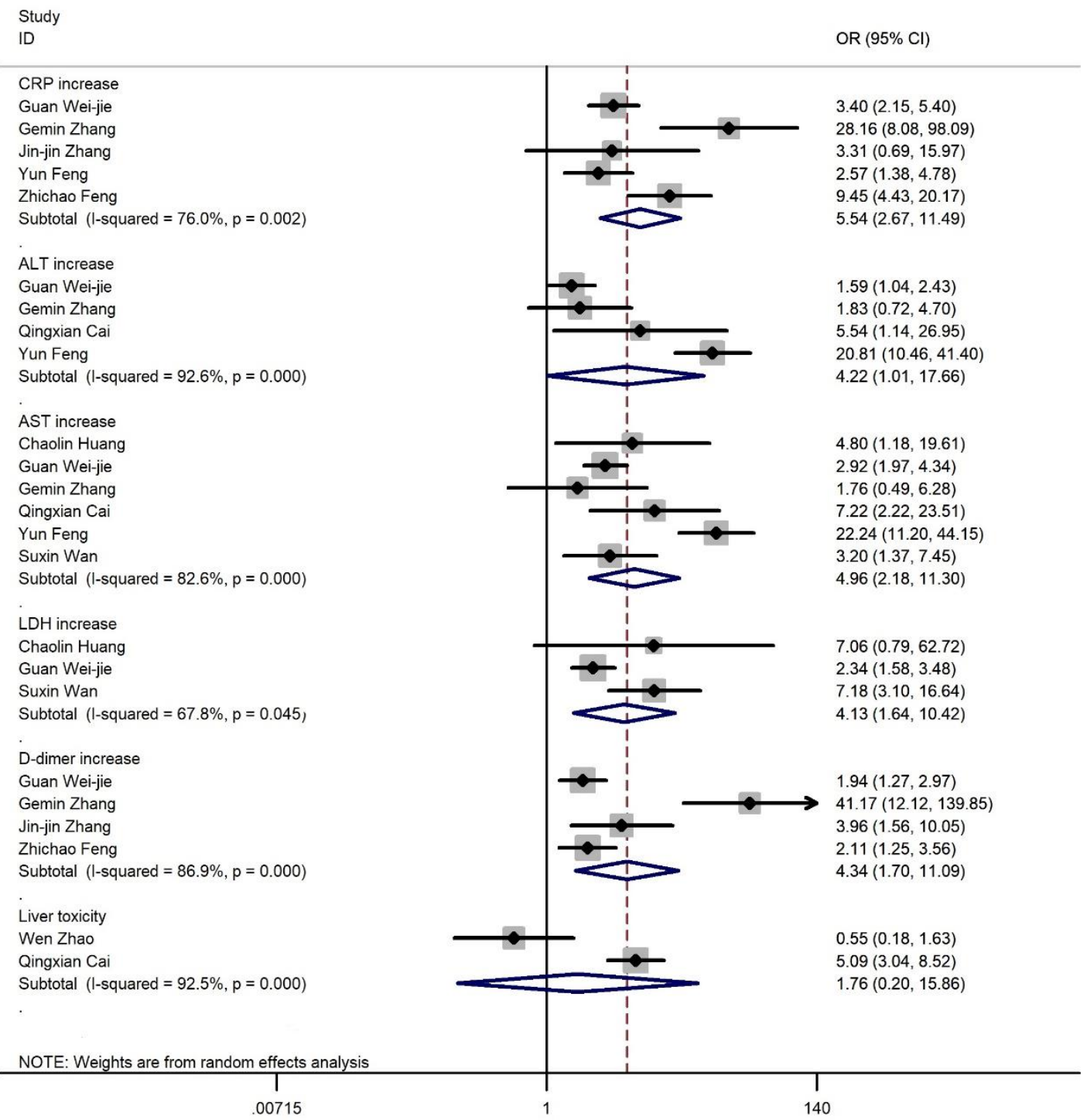

Figure 2. Forest plot for odds ratios of laboratory findings. 
medRxiv preprint doi: https://doi.org/10.1101/2020.05.20.20108357; this version posted May 23, 2020. The copyright holder for this preprint (which was not certified by peer review) is the author/funder, who has granted medRxiv a license to display the preprint in perpetuity.

All rights reserved. No reuse allowed without permission.

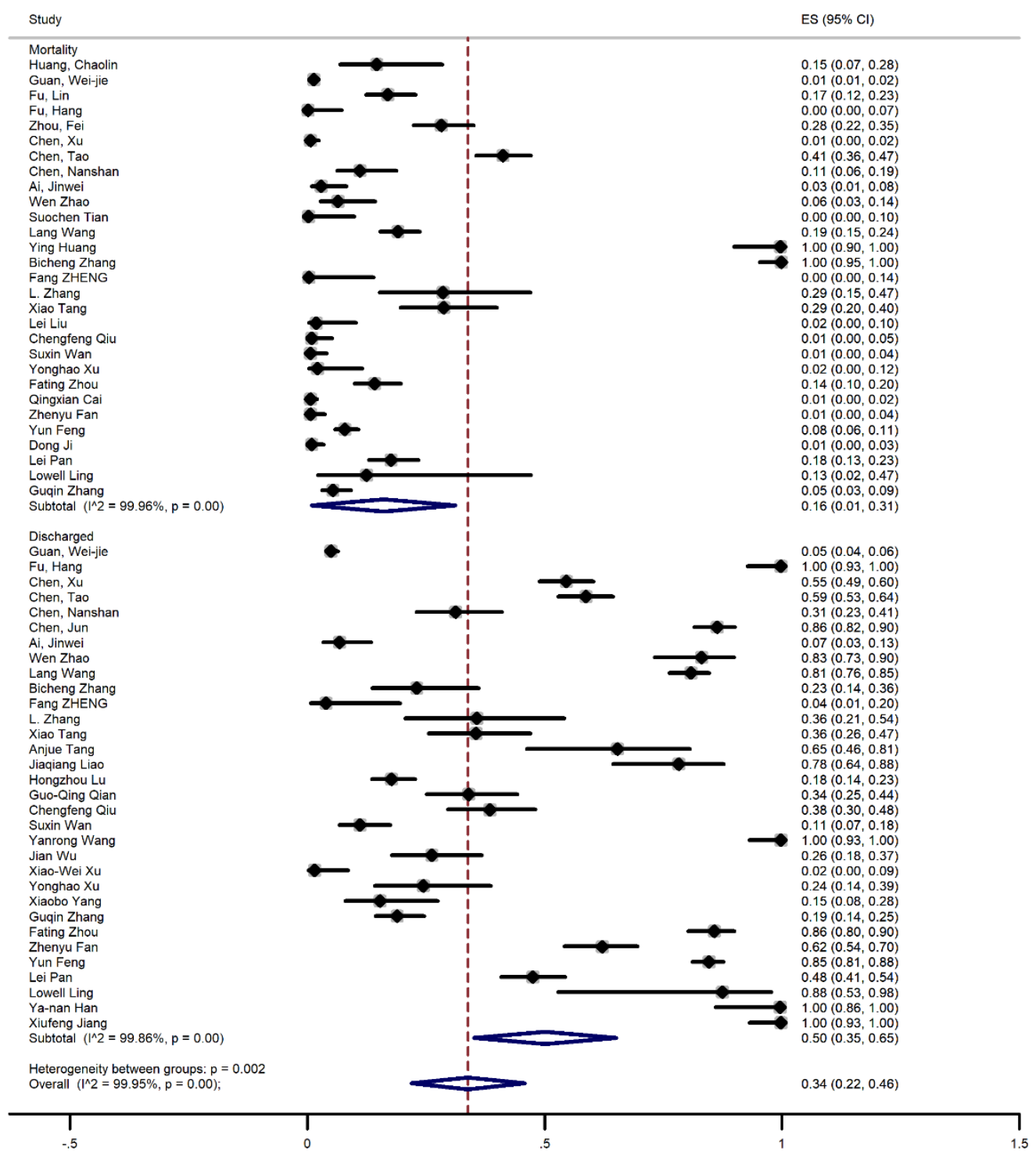

Figure 3- Meta-analysis of prevalence of clinical outcome of all patients (A) 
medRxiv preprint doi: https://doi.org/10.1101/2020.05.20.20108357; this version posted May 23, 2020. The copyright holder for this preprint (which was not certified by peer review) is the author/funder, who has granted medRxiv a license to display the preprint in perpetuity.

All rights reserved. No reuse allowed without permission.

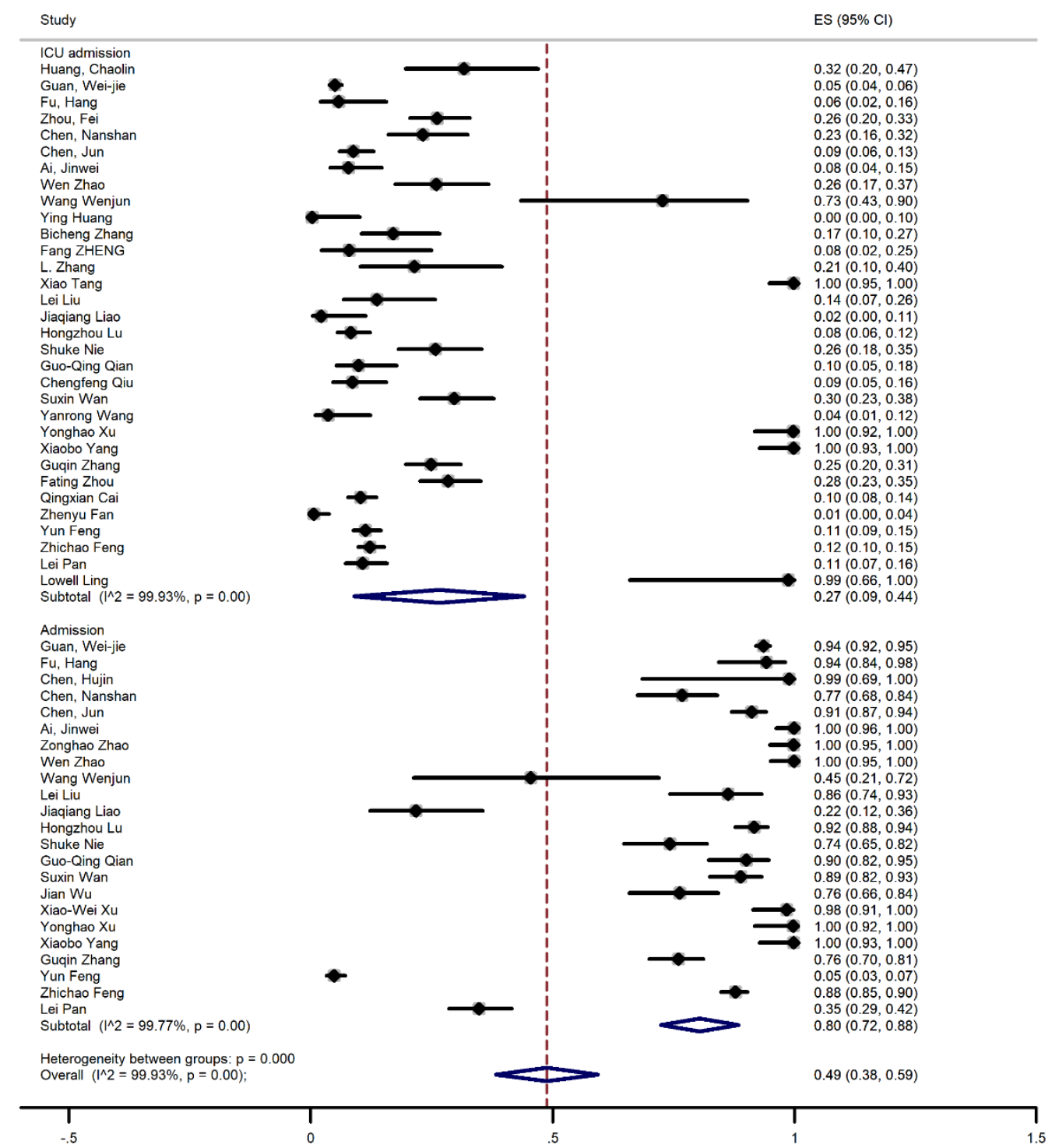

Figure 4- Meta-analysis of prevalence of clinical outcome of all patients(B) 
medRxiv preprint doi: https://doi.org/10.1101/2020.05.20.20108357; this version posted May 23, 2020. The copyright holder for this preprint (which was not certified by peer review) is the author/funder, who has granted medRxiv a license to display the preprint in perpetuity.

All rights reserved. No reuse allowed without permission.

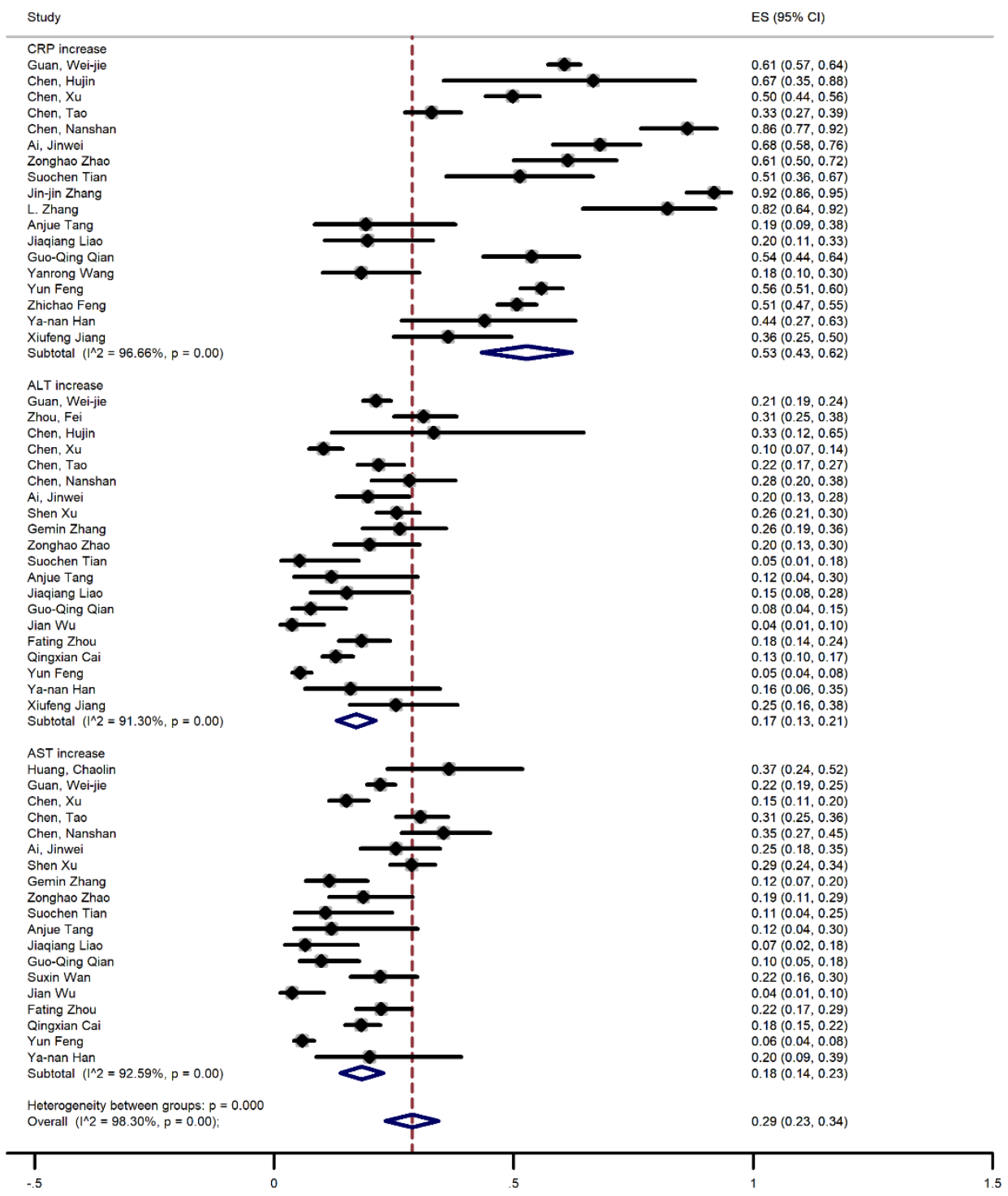

Figure 5- Meta-analysis of prevalence of laboratory findings of all patients (A) 
medRxiv preprint doi: https://doi.org/10.1101/2020.05.20.20108357; this version posted May 23, 2020. The copyright holder for this preprint (which was not certified by peer review) is the author/funder, who has granted medRxiv a license to display the preprint in perpetuity.

All rights reserved. No reuse allowed without permission.

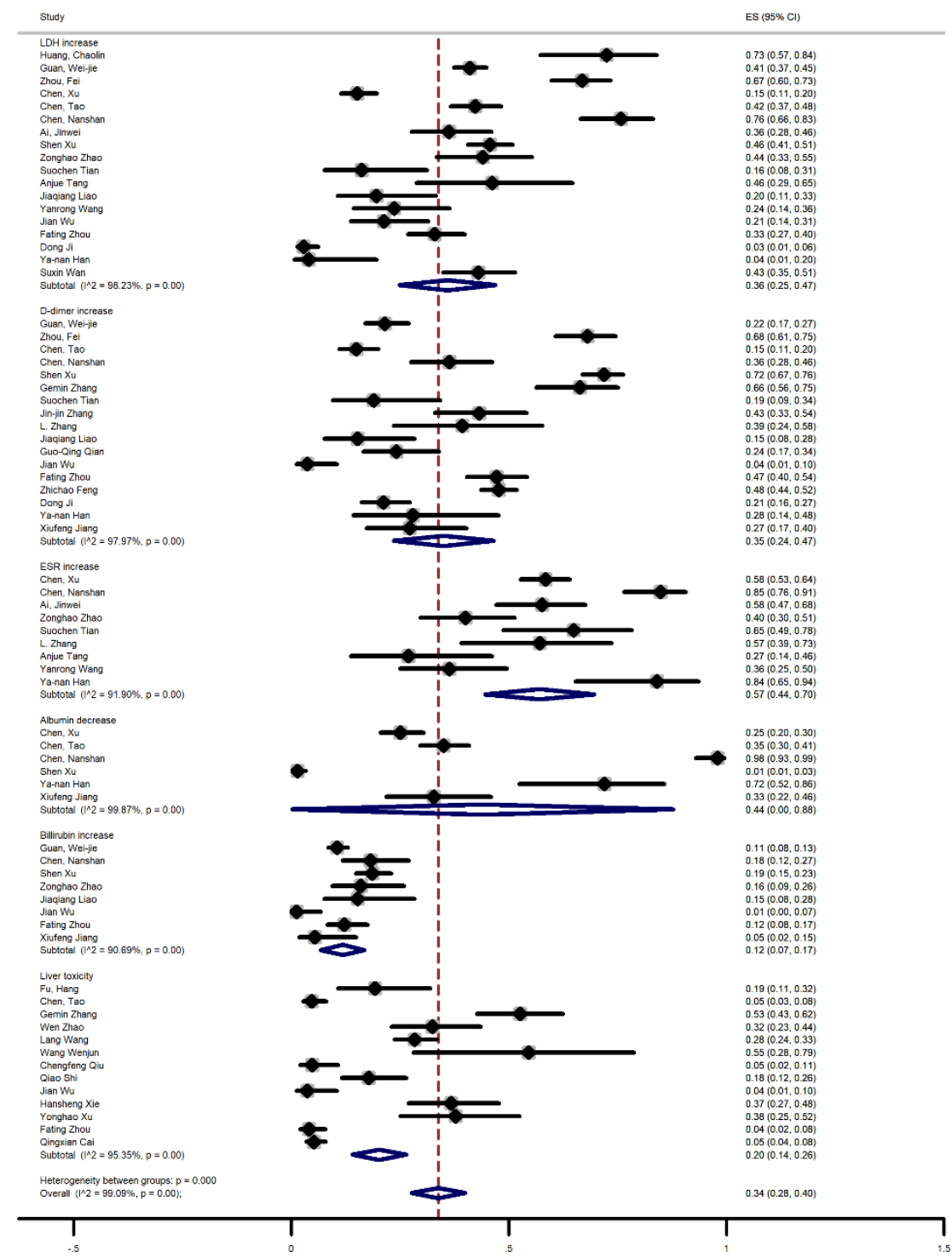

Figure 6- Meta-analysis of prevalence of laboratory findings of all patients (B) 
medRxiv preprint doi: https://doi.org/10.1101/2020.05.20.20108357; this version posted May 23, 2020. The copyright holder for this preprint (which was not certified by peer review) is the author/funder, who has granted medRxiv a license to display the preprint in perpetuity.

All rights reserved. No reuse allowed without permission.

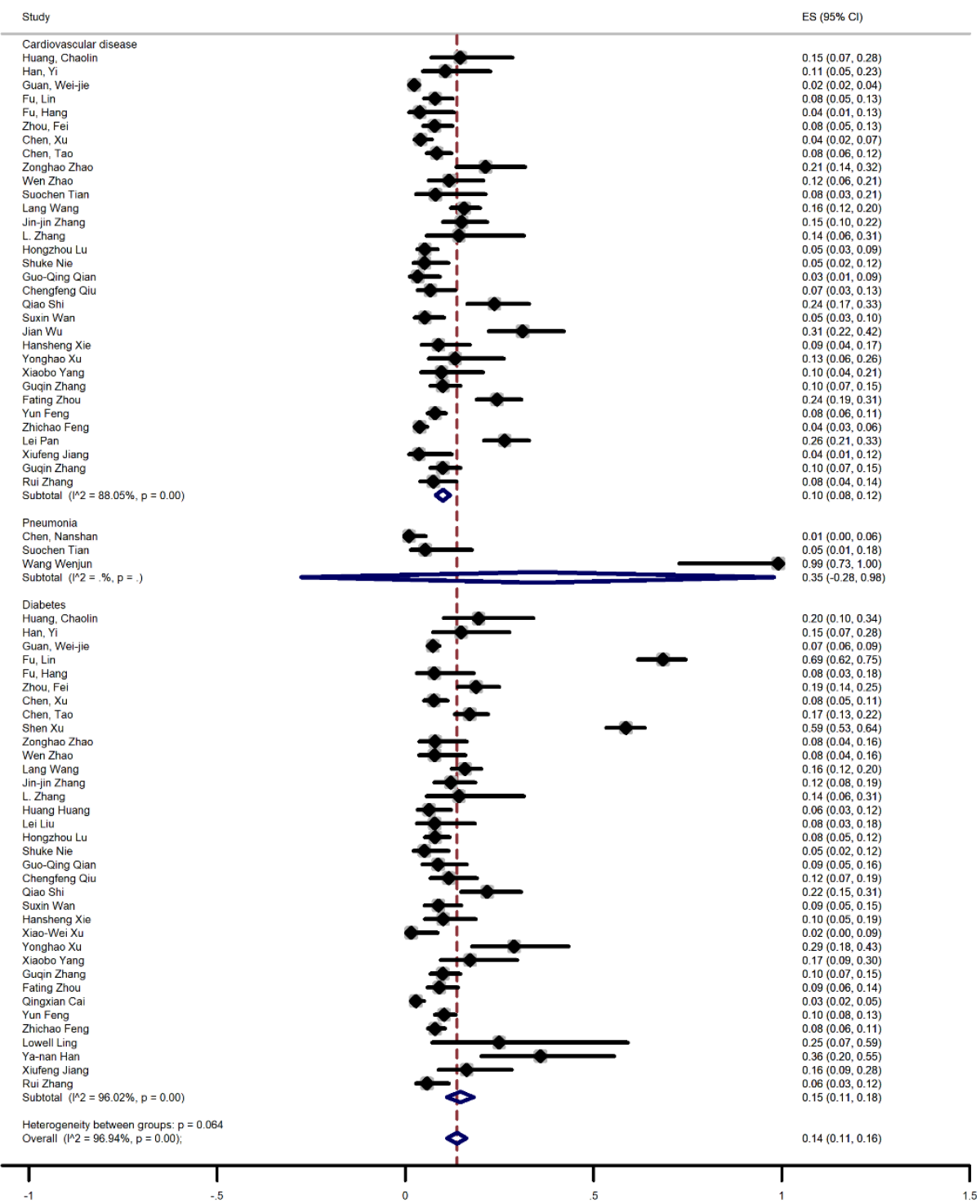

Figure 7 - Meta-analysis of prevalence of comorbidities of all patients (A) 
medRxiv preprint doi: https://doi.org/10.1101/2020.05.20.20108357; this version posted May 23, 2020. The copyright holder for this preprint (which was not certified by peer review) is the author/funder, who has granted medRxiv a license to display the preprint in perpetuity. All rights reserved. No reuse allowed without permission.

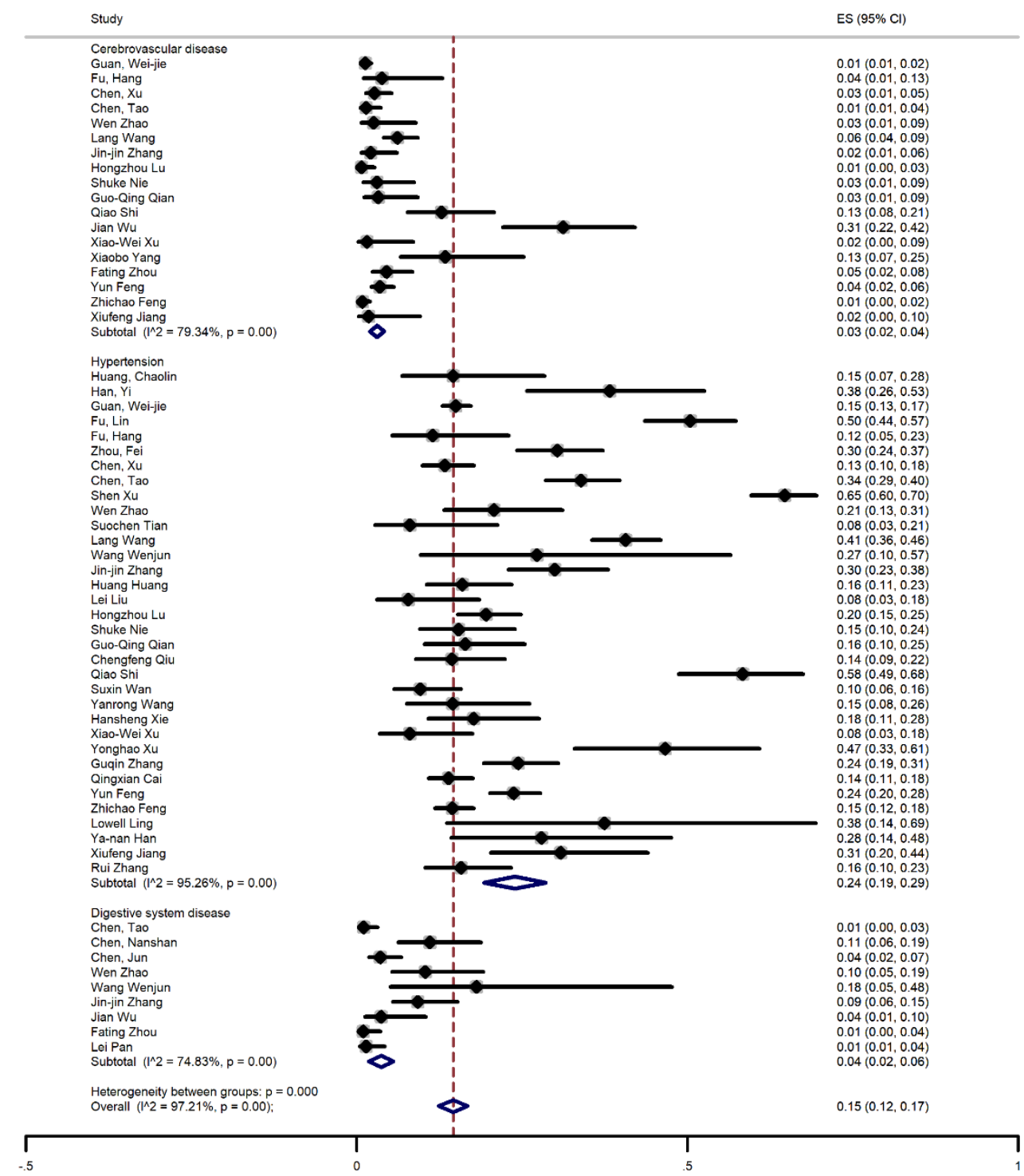

Figure 8-Meta-analysis of prevalence of comorbidities of all patients (B) 
medRxiv preprint doi: https://doi.org/10.1101/2020.05.20.20108357; this version posted May 23, 2020. The copyright holder for this preprint (which was not certified by peer review) is the author/funder, who has granted medRxiv a license to display the preprint in perpetuity. All rights reserved. No reuse allowed without permission.

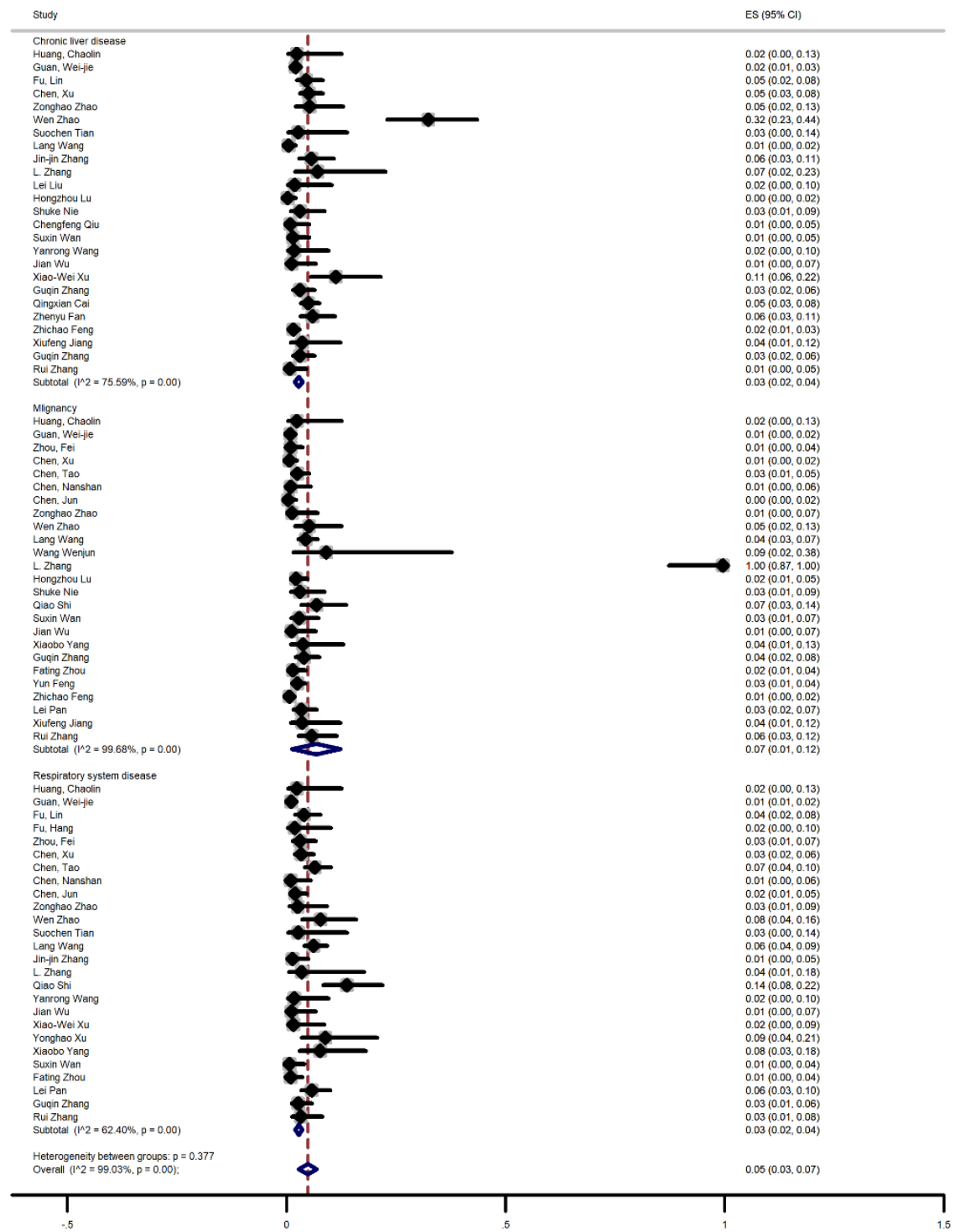

Figure 9- Meta-analysis of prevalence of comorbidities of all patients (C) 
medRxiv preprint doi: https://doi.org/10.1101/2020.05.20.20108357; this version posted May 23, 2020. The copyright holder for this preprint (which was not certified by peer review) is the author/funder, who has granted medRxiv a license to display the preprint in perpetuity. All rights reserved. No reuse allowed without permission.

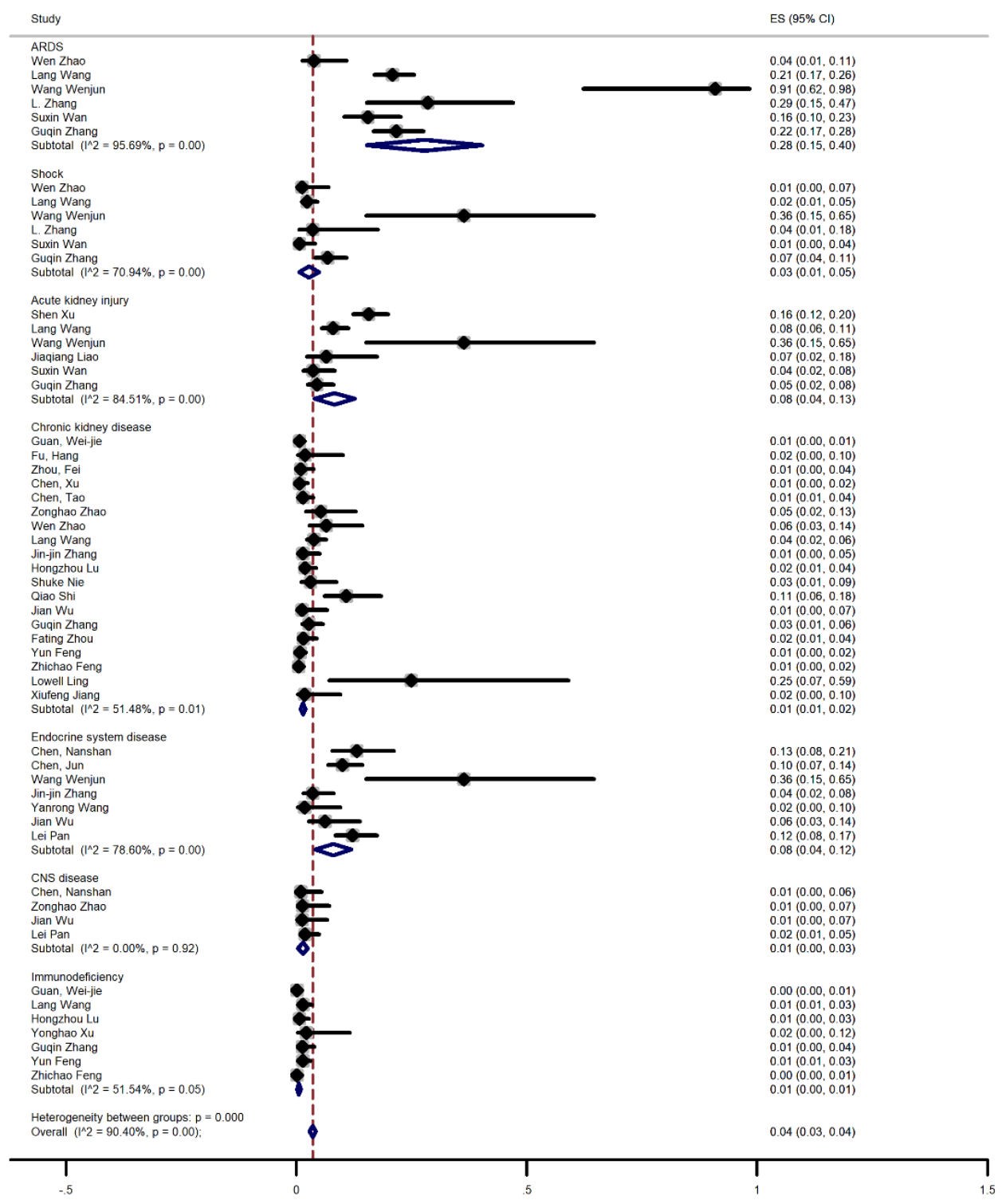

Figure 10- Meta-analysis of prevalence of comorbidities of all patients (D) 
Table 1. Characteristics of studies entered into the meta-analysis

\begin{tabular}{|c|c|c|c|c|c|c|c|c|c|c|c|c|c|c|}
\hline Author & $\begin{array}{l}\text { Countr } \\
\mathbf{y}\end{array}$ & $\begin{array}{l}\text { Type } \\
\text { of } \\
\text { study }\end{array}$ & $\begin{array}{l}\text { No. of } \\
\text { Patients } \\
\text { (male/female } \\
\text { ) }\end{array}$ & $\begin{array}{l}\text { Mean } \\
\text { Age }\end{array}$ & $\begin{array}{l}\text { Numbe } \\
\text { r of } \\
\text { patient } \\
\text { with } \\
\text { Liver } \\
\text { toxicity }\end{array}$ & $\begin{array}{l}\text { CRP } \\
(\mathrm{mg} / \mathrm{l})\end{array}$ & $\begin{array}{l}\text { ALT } \\
(\mathbf{U} / \mathbf{L})\end{array}$ & $\begin{array}{l}\text { AST } \\
(\mathbf{U} / \mathbf{L})\end{array}$ & $\begin{array}{l}\text { LDH } \\
(\mathbf{U} / \mathbf{L})\end{array}$ & $\begin{array}{l}\text { D-dimer } \\
(\mu \mathrm{g} / \mathrm{mL})\end{array}$ & $\begin{array}{l}\text { ESR } \\
(\mathrm{mm} / \mathrm{h})\end{array}$ & $\begin{array}{l}\text { Albumin } \\
(\mathrm{g} / \mathrm{L})\end{array}$ & $\begin{array}{l}\text { Bilirubin } \\
\text { (mg/dL) }\end{array}$ & $\begin{array}{l}\text { Q/A } \\
\text { score }\end{array}$ \\
\hline $\begin{array}{l}\text { Huang, } \\
\text { Chaoli } \\
\text { n (11) }\end{array}$ & China & $\begin{array}{l}\text { cross } \\
\text { section } \\
\text { al }\end{array}$ & $\begin{array}{l}41 \\
(30 / 11)\end{array}$ & $\begin{array}{l}49.0 \\
(41.0- \\
58.0)\end{array}$ & - & - & $\begin{array}{l}32.0 \\
(21.0- \\
50.0)\end{array}$ & - & $\begin{array}{l}286.0 \\
(242.0- \\
408.0)\end{array}$ & $0 \cdot 5(0 \cdot 3-1 \cdot 3)$ & - & $\begin{array}{l}31.4(28.9- \\
36.0)\end{array}$ & - & 8 \\
\hline $\begin{array}{l}\text { Han, } \\
\text { Yi(34) }\end{array}$ & China & $\begin{array}{l}\text { cross } \\
\text { section } \\
\text { al }\end{array}$ & $\begin{array}{l}47 \\
(26 / 21)\end{array}$ & $\begin{array}{l}64.91 \\
(31-87)\end{array}$ & - & 57.52 & $\begin{array}{l}27.0 \\
(17.25- \\
49)\end{array}$ & 39.45 & 357.85 & $\begin{array}{l}1.07(0.48- \\
4.93)\end{array}$ & - & - & - & 8 \\
\hline $\begin{array}{l}\text { Guan, } \\
\text { Wei- } \\
\text { jie(64) }\end{array}$ & China & $\begin{array}{l}\text { cross } \\
\text { section } \\
\text { al }\end{array}$ & $\begin{array}{l}1099 \\
(637 / 459)\end{array}$ & $\begin{array}{l}47.0 \\
(35.0- \\
58.0)\end{array}$ & - & - & - & - & - & - & - & - & - & 9 \\
\hline $\begin{array}{l}\mathrm{Fu}, \mathrm{Lin} \\
(65) \\
(2020)\end{array}$ & China & $\begin{array}{l}\text { cross } \\
\text { section } \\
\text { al }\end{array}$ & $\begin{array}{l}200 \\
(99 / 101)\end{array}$ & - & - & - & $\begin{array}{l}23.5(16 \\
0-42.0)\end{array}$ & $\begin{array}{l}35(23.4- \\
56.8)\end{array}$ & $\begin{array}{l}274(190- \\
403)\end{array}$ & - & - & - & - & 8 \\
\hline $\begin{array}{l}\text { Fu, } \\
\text { Hang }(6 \\
6)\end{array}$ & China & $\begin{array}{l}\text { cross } \\
\text { section } \\
\text { al }\end{array}$ & $\begin{array}{l}52 \\
(28 / 24)\end{array}$ & $\begin{array}{l}44.5 \\
(33.0- \\
56.5)\end{array}$ & 10 & $\begin{array}{l}8.8(3.5- \\
21.4)\end{array}$ & $\begin{array}{l}24.0(15 . \\
3-39.0)\end{array}$ & $\begin{array}{l}27.0(21 . \\
2-34.0)\end{array}$ & $\begin{array}{l}224(200- \\
253)\end{array}$ & $\begin{array}{l}0.69(0.54- \\
0.84)\end{array}$ & - & - & - & 9 \\
\hline
\end{tabular}




\begin{tabular}{|c|c|c|c|c|c|c|c|c|c|c|c|c|c|c|}
\hline $\begin{array}{l}\text { Zhou, } \\
\text { Fei(67) }\end{array}$ & China & $\begin{array}{l}\text { cross } \\
\text { section } \\
\text { al }\end{array}$ & $\begin{array}{l}191 \\
(119 / 72)\end{array}$ & $\begin{array}{l}56.0 \\
(46.0- \\
67.0)\end{array}$ & - & - & $\begin{array}{l}30.0 \\
(17.0- \\
46.0)\end{array}$ & - & $\begin{array}{l}300.0(234 . \\
0-407.0)\end{array}$ & $0.8(0.4-3.2)$ & - & $\begin{array}{l}32.3(29.1- \\
35.8)\end{array}$ & - & 9 \\
\hline $\begin{array}{l}\text { Chen, } \\
\text { Hujin(6 } \\
\text { 8) }\end{array}$ & China & $\begin{array}{l}\text { Case } \\
\text { series }\end{array}$ & $\begin{array}{l}9 \\
(0 / 9)\end{array}$ & 29.89 & - & 18.61 & 253.77 & 171 & - & - & - & - & - & 9 \\
\hline $\begin{array}{l}\text { Chen, } \\
\mathrm{Xu}(69)\end{array}$ & China & $\begin{array}{l}\text { cross } \\
\text { section } \\
\text { al }\end{array}$ & $\begin{array}{l}291 \\
(145 / 146)\end{array}$ & $\begin{array}{l}46.0 \\
(34.0- \\
59.0)\end{array}$ & - & $\begin{array}{l}15.6 \\
(4.4- \\
30.3)\end{array}$ & $\begin{array}{l}20.7 \\
(14.9- \\
28.9)\end{array}$ & $\begin{array}{l}24.7 \\
(19.9- \\
31.4)\end{array}$ & $\begin{array}{l}172.8 \\
(142.6- \\
220.5)\end{array}$ & - & $\begin{array}{l}37.0 \\
(21.0- \\
62.0)\end{array}$ & $\begin{array}{l}37.3(34.7- \\
40.3)\end{array}$ & 27 & 9 \\
\hline $\begin{array}{l}\text { Chen, } \\
\text { Tao(70 } \\
\text { ) }\end{array}$ & China & $\begin{array}{l}\text { cross } \\
\text { section } \\
\text { al }\end{array}$ & $\begin{array}{l}274 \\
(171 / 103)\end{array}$ & $\begin{array}{l}62.0 \\
(44.0- \\
70.0)\end{array}$ & 13 & $\begin{array}{l}53.4 \\
(18.6- \\
113.0)\end{array}$ & $\begin{array}{l}23.0 \\
(15.0- \\
38.0)\end{array}$ & $\begin{array}{l}30.0 \\
(22.0- \\
46.0)\end{array}$ & $\begin{array}{l}321.5 \\
(249.8- \\
510.5)\end{array}$ & $1.1(0.5-3.2)$ & $\begin{array}{l}32.5 \\
(17.3- \\
53.8)\end{array}$ & $\begin{array}{l}33.9(30.3- \\
37.6)\end{array}$ & - & 9 \\
\hline $\begin{array}{l}\text { Chen, } \\
\text { Nansha } \\
\text { n(71) }\end{array}$ & China & $\begin{array}{l}\text { cross } \\
\text { section } \\
\text { al }\end{array}$ & $\begin{array}{l}99 \\
(67 / 32)\end{array}$ & $\begin{array}{l}55.5(21- \\
82)\end{array}$ & - & 51.4 & $\begin{array}{l}39.0 \\
(22.0- \\
53.0)\end{array}$ & $\begin{array}{l}34.0 \\
(26.0- \\
48.0)\end{array}$ & $\begin{array}{l}336.0 \\
(260.0- \\
447.0)\end{array}$ & $0.9(0.5-2.8)$ & 49.9 & 31.6 & 15.1 & 7 \\
\hline $\begin{array}{l}\text { Chen, } \\
\text { Jun(72) }\end{array}$ & China & $\begin{array}{l}\text { cross } \\
\text { section } \\
\text { al }\end{array}$ & $\begin{array}{l}249 \\
(126 / 123)\end{array}$ & $51(36-64)$ & - & $\begin{array}{l}12(4.4- \\
29.4)\end{array}$ & $\begin{array}{l}23(15- \\
33)\end{array}$ & $\begin{array}{l}25(20- \\
33)\end{array}$ & $\begin{array}{l}229(195- \\
291)\end{array}$ & - & $\begin{array}{l}54(33- \\
90)\end{array}$ & $\begin{array}{l}40.8(37.9- \\
43.0)\end{array}$ & - & 8 \\
\hline $\begin{array}{l}\text { Ai, } \\
\text { Jinwei } \\
(73)\end{array}$ & China & $\begin{array}{l}\text { cross } \\
\text { section } \\
\text { al }\end{array}$ & $\begin{array}{l}102 \\
(52 / 50)\end{array}$ & $\begin{array}{l}50.38(1.5 \\
-90)\end{array}$ & - & 28.16 & 27.77 & 30.59 & 245.38 & - & 33.30 & - & - & 7 \\
\hline $\begin{array}{l}\text { Shen } \\
\mathrm{Xu} \\
(74)\end{array}$ & China & $\begin{array}{l}\text { cross } \\
\text { section } \\
\text { al }\end{array}$ & $\begin{array}{l}355 \\
(162 / 193)\end{array}$ & - & - & & $\begin{array}{l}35.0(1- \\
414)\end{array}$ & $\begin{array}{l}40.76(1 \\
0-475)\end{array}$ & 296.4 & $\begin{array}{l}2.76(0.1- \\
382)\end{array}$ & - & $\begin{array}{l}38.53(18.2- \\
56.1)\end{array}$ & $\begin{array}{l}14.16(0.7 \\
-511.6)\end{array}$ & 9 \\
\hline $\begin{array}{l}\text { Gemin } \\
\text { Zhang } \\
\text { (75) }\end{array}$ & China & $\begin{array}{l}\text { cross } \\
\text { section } \\
\text { al }\end{array}$ & $\begin{array}{l}95 \\
(42 / 53)\end{array}$ & $49(39-58)$ & 50 & 25 & - & - & - & - & - & - & - & 9 \\
\hline
\end{tabular}




\begin{tabular}{|c|c|c|c|c|c|c|c|c|c|c|c|c|c|}
\hline $\begin{array}{l}\text { Zongha } \\
\text { o Zhao } \\
\text { (10) }\end{array}$ & China & $\begin{array}{l}\text { cross } \\
\text { section } \\
\text { al }\end{array}$ & $\begin{array}{l}75 \\
(33 / 42)\end{array}$ & $47(34-55)$ & - & $\begin{array}{l}13.6(3 . \\
8-48.2)\end{array}$ & $\begin{array}{l}23(14- \\
43)\end{array}$ & $\begin{array}{l}27(21- \\
37)\end{array}$ & $\begin{array}{l}233(176.5- \\
313)\end{array}$ & - & $\begin{array}{l}30.1(11 . \\
5-69)\end{array}$ & - & $\begin{array}{l}14.5(11.1 \\
-18.2)\end{array}$ \\
\hline $\begin{array}{l}\text { Wen } \\
\text { Zhao } \\
(76)\end{array}$ & China & $\begin{array}{l}\text { cross } \\
\text { section } \\
\text { al }\end{array}$ & $\begin{array}{l}77 \\
(34 / 43)\end{array}$ & 52 & 25 & $\begin{array}{l}17(4.6- \\
51.1)\end{array}$ & $\begin{array}{l}28(20- \\
46)\end{array}$ & $\begin{array}{l}29(21- \\
42)\end{array}$ & - & - & - & - & - \\
\hline $\begin{array}{l}\text { Suoche } \\
\text { n Tian } \\
\text { (77) }\end{array}$ & China & $\begin{array}{l}\text { cross } \\
\text { section } \\
\text { al }\end{array}$ & $\begin{array}{l}37 \\
(17 / 20)\end{array}$ & 44.3 & - & & - & - & - & - & - & - & - \\
\hline $\begin{array}{l}\text { Lang } \\
\text { Wang } \\
\text { (78) }\end{array}$ & China & $\begin{array}{l}\text { cross } \\
\text { section } \\
\text { al }\end{array}$ & $\begin{array}{l}339 \\
(166 / 173)\end{array}$ & 71 & 96 & $\begin{array}{l}49.6(18 \\
.5-93.2)\end{array}$ & $\begin{array}{l}27(17- \\
44)\end{array}$ & $\begin{array}{l}32(23- \\
46)\end{array}$ & $\begin{array}{l}301(224- \\
429)\end{array}$ & $\begin{array}{l}1.2(0.62- \\
3.25)\end{array}$ & - & - & - \\
\hline $\begin{array}{l}\text { Wang } \\
\text { Wenju } \\
\text { n (79) }\end{array}$ & China & $\begin{array}{l}\text { cross } \\
\text { section } \\
\text { al }\end{array}$ & $\begin{array}{l}11 \\
(10 / / 1)\end{array}$ & $58(49-72)$ & 6 & $\begin{array}{l}12.06(6 \\
.24- \\
13.75)\end{array}$ & $\begin{array}{l}24(15.9- \\
27.7)\end{array}$ & - & $\begin{array}{l}396.5(357 . \\
6-529)\end{array}$ & $1.31(6.7-4.7)$ & - & $\begin{array}{l}33.6(30.5- \\
37.2)\end{array}$ & $\begin{array}{l}15.1(11.2 \\
-20.4)\end{array}$ \\
\hline $\begin{array}{l}\text { Ying } \\
\text { Huang } \\
(80)\end{array}$ & China & $\begin{array}{l}\text { cross } \\
\text { section } \\
\text { al }\end{array}$ & $\begin{array}{l}36 \\
(25 / 11)\end{array}$ & 69.22 & 22 & $\begin{array}{l}106.2 \\
(60.83- \\
225.3)\end{array}$ & $\begin{array}{l}26(18- \\
38)\end{array}$ & $\begin{array}{l}43(30- \\
51)\end{array}$ & $\begin{array}{l}502.5(410- \\
629)\end{array}$ & $\begin{array}{l}8.64(2.39- \\
20)\end{array}$ & - & 30.18 & $\begin{array}{l}11.21 \\
(7.5-19.2)\end{array}$ \\
\hline $\begin{array}{l}\text { Bichen } \\
\text { g } \\
\text { Zhang } \\
(81)\end{array}$ & China & $\begin{array}{l}\text { cross } \\
\text { section } \\
\text { al }\end{array}$ & $\begin{array}{l}82 \\
(54 / 28)\end{array}$ & 72.5 & 64 & $\begin{array}{l}11.7 \\
(63.3- \\
186.6)\end{array}$ & $\begin{array}{l}26.0 \\
(18.5- \\
47.5)\end{array}$ & $\begin{array}{l}72.0 \\
(30.0- \\
71.0)\end{array}$ & $\begin{array}{l}515.0 \\
(365.0- \\
755.0)\end{array}$ & $\begin{array}{l}5.1(2.2- \\
21.5)\end{array}$ & - & $\begin{array}{l}33.1(30.3- \\
36.9)\end{array}$ & $\begin{array}{l}13.6 \\
(10.0- \\
22.9)\end{array}$ \\
\hline $\begin{array}{l}\text { Jin-jin } \\
\text { Zhang } \\
\text { (82) }\end{array}$ & China & $\begin{array}{l}\text { cross } \\
\text { section } \\
\text { al }\end{array}$ & $\begin{array}{l}140 \\
(71 / 69)\end{array}$ & 57 & - & $\begin{array}{l}34.2 \\
(12.5- \\
67.4)\end{array}$ & - & - & - & $0.2(0.1-0.5)$ & - & - & - \\
\hline
\end{tabular}




\begin{tabular}{|c|c|c|c|c|c|c|c|c|c|c|c|c|c|}
\hline $\begin{array}{l}\text { Fang } \\
\text { ZHEN } \\
\text { G (83) }\end{array}$ & China & $\begin{array}{l}\text { cross } \\
\text { section } \\
\text { al }\end{array}$ & $\begin{array}{l}25 \\
(14 / 11)\end{array}$ & 3 & - & - & - & - & - & - & - & - & - \\
\hline $\begin{array}{l}\text { L. } \\
\text { Zhang } \\
(84)\end{array}$ & China & $\begin{array}{l}\text { cross } \\
\text { section } \\
\text { al }\end{array}$ & $\begin{array}{l}28 \\
(17 / 11)\end{array}$ & 65.0 & - & - & - & - & $\begin{array}{l}262.9 \\
(168.5- \\
508.0)\end{array}$ & - & - & $\begin{array}{l}31.1(28.6- \\
34.8)\end{array}$ & - \\
\hline $\begin{array}{l}\text { Yishan } \\
\text { Zheng } \\
(85)\end{array}$ & China & $\begin{array}{l}\text { cross } \\
\text { section } \\
\text { al }\end{array}$ & $\begin{array}{l}103 \\
(55 / 48)\end{array}$ & - & - & - & - & - & - & - & - & - & - \\
\hline $\begin{array}{l}\text { Dahai } \\
\text { Zhao } \\
(86)\end{array}$ & China & $\begin{array}{l}\text { cross } \\
\text { section } \\
\text { al }\end{array}$ & $\begin{array}{l}34 \\
(11 / 8)\end{array}$ & 48 & - & $\begin{array}{l}26.47 \\
(10- \\
127.1)\end{array}$ & $\begin{array}{l}36.37 \\
(11.8- \\
85.0)\end{array}$ & $\begin{array}{l}34.9 \\
(17.6- \\
103.8)\end{array}$ & $\begin{array}{l}256.94 \\
(150-750)\end{array}$ & - & - & - & - \\
\hline $\begin{array}{l}\text { Xiao } \\
\text { Tang } \\
(87)\end{array}$ & China & $\begin{array}{l}\text { cross } \\
\text { section } \\
\text { al }\end{array}$ & $\begin{array}{l}73 \\
(45 / 28)\end{array}$ & 67 & 33 & $\begin{array}{l}87.2 \\
(32.6- \\
104.5)\end{array}$ & $\begin{array}{l}34.5 \\
(24.0- \\
61.0)\end{array}$ & $\begin{array}{l}25.5 \\
(20.0- \\
42.5)\end{array}$ & $\begin{array}{l}483.0 \\
(351.0 \\
602.0)\end{array}$ & $0.6(0.4-3.4)$ & - & $\begin{array}{l}33.2(30.8- \\
36.2)\end{array}$ & $\begin{array}{l}9.8(8.0- \\
14.5)\end{array}$ \\
\hline $\begin{array}{l}\text { Huang } \\
\text { Huang } \\
(88)\end{array}$ & China & $\begin{array}{l}\text { cross } \\
\text { section } \\
\text { al }\end{array}$ & $\begin{array}{l}125 \\
(63 / 62)\end{array}$ & 44.87 & - & $\begin{array}{l}6.32(1 . \\
63- \\
23.50)\end{array}$ & $\begin{array}{l}18.90(1 \\
3.40- \\
25.20)\end{array}$ & $\begin{array}{l}18.40(1 \\
4.20- \\
7015)\end{array}$ & $\begin{array}{l}175(150- \\
241.5)\end{array}$ & - & - & 38.30 & - \\
\hline $\begin{array}{l}\text { Anjue } \\
\text { Tang } \\
(89)\end{array}$ & China & $\begin{array}{l}\text { cross } \\
\text { section } \\
\text { al }\end{array}$ & $\begin{array}{l}26 \\
(17 / 9)\end{array}$ & 6.9 & - & - & - & - & - & - & - & - & - \\
\hline $\begin{array}{l}\text { Lei Liu } \\
(90)\end{array}$ & China & $\begin{array}{l}\text { cross } \\
\text { section } \\
\text { al }\end{array}$ & $\begin{array}{l}51 \\
(32 / 19)\end{array}$ & $\begin{array}{l}45(34- \\
51)\end{array}$ & - & $\begin{array}{l}10.5( \\
2.7- \\
51.2)\end{array}$ & $\begin{array}{l}18 \\
30)\end{array}$ & $\begin{array}{l}21(16- \\
30)\end{array}$ & $\begin{array}{l}231 \\
276)\end{array}$ & $\begin{array}{l}0.28 \\
0.51)\end{array}$ & - & $\begin{array}{l}40 \quad(36-43 \\
)\end{array}$ & - \\
\hline $\begin{array}{l}\text { Jiaqian } \\
\text { g Liao } \\
(91)\end{array}$ & China & $\begin{array}{l}\text { cross } \\
\text { section } \\
\text { al }\end{array}$ & $\begin{array}{l}46 \\
(24 / 22)\end{array}$ & - & - & $\begin{array}{l}2.6 \\
(0.8- \\
9.4)\end{array}$ & $\begin{array}{l}17.9 \\
(11.6- \\
32.5)\end{array}$ & $\begin{array}{l}18.3 \\
(14.5- \\
26.9)\end{array}$ & $\begin{array}{l}195.5 \\
(145.0- \\
240.0)\end{array}$ & $0.3(0.2-0.4)$ & - & - & $\begin{array}{l}8.7(5.9- \\
14.6)\end{array}$ \\
\hline
\end{tabular}




\begin{tabular}{|c|c|c|c|c|c|c|c|c|c|c|c|c|c|}
\hline $\begin{array}{l}\text { Hongz } \\
\text { hou Lu } \\
\text { (5) }\end{array}$ & China & $\begin{array}{l}\text { cross } \\
\text { section } \\
\text { al }\end{array}$ & 265 & - & - & $\begin{array}{l}9.8 \\
(2.5- \\
27.4)\end{array}$ & $\begin{array}{l}23.0 \\
(15.0- \\
33.0)\end{array}$ & $\begin{array}{l}24.0 \\
(19.0- \\
33.0)\end{array}$ & $\begin{array}{l}232(195- \\
293)\end{array}$ & $\begin{array}{l}0.42(0.29- \\
0.80)\end{array}$ & - & $\begin{array}{l}40.8(37.8- \\
43.0)\end{array}$ & $\begin{array}{l}7.90(6.5- \\
10.5)\end{array}$ \\
\hline $\begin{array}{l}\text { Shuke } \\
\text { Nie } \\
(92)\end{array}$ & China & $\begin{array}{l}\text { cross } \\
\text { section } \\
\text { al }\end{array}$ & $\begin{array}{l}97 \\
(34 / 63)\end{array}$ & $39(30-60)$ & - & - & - & - & - & - & - & - & - \\
\hline $\begin{array}{l}\text { Guo- } \\
\text { Qing } \\
\text { Qian } \\
(93)\end{array}$ & China & $\begin{array}{l}\text { cross } \\
\text { section } \\
\text { al }\end{array}$ & $\begin{array}{l}91 \\
(37 / 54)\end{array}$ & $\begin{array}{l}50(36.5- \\
57)\end{array}$ & - & $\begin{array}{l}6.81(1 . \\
87- \\
15.30)\end{array}$ & $\begin{array}{l}18(13- \\
28)\end{array}$ & $\begin{array}{l}21(17- \\
28)\end{array}$ & - & $\begin{array}{l}0.3(0.11- \\
0.45)\end{array}$ & - & $\begin{array}{l}40(37.85- \\
42)\end{array}$ & - \\
\hline $\begin{array}{l}\text { Chengf } \\
\text { eng } \\
\text { Qiu } \\
(94)\end{array}$ & China & $\begin{array}{l}\text { cross } \\
\text { section } \\
\text { al }\end{array}$ & $\begin{array}{l}104 \\
(49 / 55)\end{array}$ & 43 & 5 & $\begin{array}{l}11.75 \\
(3.55- \\
32.73)\end{array}$ & $\begin{array}{l}20.00 \\
(15.00- \\
34.25)\end{array}$ & $\begin{array}{l}26.00 \\
(20.83- \\
34.08)\end{array}$ & - & $\begin{array}{l}0.47(0.19- \\
0.70)\end{array}$ & - & 37.35 & $\begin{array}{l}10.90 \\
(7.55- \\
16.65)\end{array}$ \\
\hline $\begin{array}{l}\text { Qiao } \\
\text { Shi } \\
(95)\end{array}$ & China & $\begin{array}{l}\text { cross } \\
\text { section } \\
\text { al }\end{array}$ & $\begin{array}{l}101 \\
(60 / 41)\end{array}$ & - & 18 & 107.9 & 55.99 & 116.8 & - & - & - & - & 25.01 \\
\hline $\begin{array}{l}\text { Suxin } \\
\text { Wan } \\
\text { (96) }\end{array}$ & China & $\begin{array}{l}\text { cross } \\
\text { section } \\
\text { al }\end{array}$ & $\begin{array}{l}135 \\
(72 / 63)\end{array}$ & $47(36-55)$ & - & $\begin{array}{l}10.5(2 . \\
7-51.2)\end{array}$ & $\begin{array}{l}26(12.9- \\
33.15)\end{array}$ & $\begin{array}{l}33.4(27 . \\
8-43.7)\end{array}$ & $\begin{array}{l}320.5(248 \\
5-385.3)\end{array}$ & $0.4(0.2-0.6)$ & - & $\begin{array}{l}40.5(37- \\
43.4)\end{array}$ & $\begin{array}{l}8.6(5.9- \\
13.7)\end{array}$ \\
\hline $\begin{array}{l}\text { Yanron } \\
\text { g } \\
\text { Wang } \\
(97)\end{array}$ & China & $\begin{array}{l}\text { cross } \\
\text { section } \\
\text { al }\end{array}$ & $\begin{array}{l}55 \\
(22 / 33)\end{array}$ & $49(2-69)$ & - & - & - & - & - & - & - & - & - \\
\hline $\begin{array}{l}\text { Yafei } \\
\text { Wang } \\
(98)\end{array}$ & China & $\begin{array}{l}\text { cross } \\
\text { section } \\
\text { al }\end{array}$ & $\begin{array}{l}110 \\
(48 / 62)\end{array}$ & - & - & - & - & - & - & - & - & - & - \\
\hline
\end{tabular}




\begin{tabular}{|c|c|c|c|c|c|c|c|c|c|c|c|c|c|}
\hline $\begin{array}{l}\text { Jian } \\
\mathrm{Wu} \\
(99)\end{array}$ & China & $\begin{array}{l}\text { cross } \\
\text { section } \\
\text { al }\end{array}$ & $\begin{array}{l}80 \\
(39 / 41)\end{array}$ & 46.1 & 3 & $\begin{array}{l}6.6(5.3- \\
12.3)\end{array}$ & $\begin{array}{l}24(12- \\
38)\end{array}$ & $\begin{array}{l}30(19- \\
39)\end{array}$ & $\begin{array}{l}226(182- \\
308)\end{array}$ & $0.9(0.4-2.4)$ & & $\begin{array}{l}38.3(37.0- \\
46.2)\end{array}$ & $\begin{array}{l}6.6(5.4- \\
12.0)\end{array}$ \\
\hline $\begin{array}{l}\text { Hanshe } \\
\text { ng Xie } \\
(100)\end{array}$ & China & $\begin{array}{l}\text { cross } \\
\text { section } \\
\text { al }\end{array}$ & $\begin{array}{l}79 \\
(44 / 35)\end{array}$ & $\begin{array}{l}60.0 \\
(48.0- \\
66.0)\end{array}$ & 29 & $\begin{array}{l}13.9 \\
(3.1- \\
51.9)\end{array}$ & $\begin{array}{l}34(18- \\
67)\end{array}$ & $\begin{array}{l}30(23- \\
50)\end{array}$ & - & $\begin{array}{l}0.69(0.33- \\
1.35)\end{array}$ & $\begin{array}{l}39(24- \\
58)\end{array}$ & - & $\begin{array}{l}13.6(8.8- \\
17.6)\end{array}$ \\
\hline $\begin{array}{l}\text { Xiao- } \\
\text { Wei } \\
\text { Xu } \\
(101)\end{array}$ & China & $\begin{array}{l}\text { cross } \\
\text { section } \\
\text { al }\end{array}$ & $\begin{array}{l}62 \\
(35 / 27)\end{array}$ & $\begin{array}{l}41(32- \\
52)\end{array}$ & - & - & $\begin{array}{l}22(14- \\
34)\end{array}$ & $\begin{array}{l}26(20- \\
32)\end{array}$ & $\begin{array}{l}205.0 \\
(184.0- \\
260.5)\end{array}$ & $0.2(0.2-0.5)$ & - & - & - \\
\hline $\begin{array}{l}\text { Yongh } \\
\text { ao Xu } \\
(102)\end{array}$ & China & $\begin{array}{l}\text { cross } \\
\text { section } \\
\text { al }\end{array}$ & $\begin{array}{l}45 \\
(29 / 16)\end{array}$ & 56.7 & 17 & & $\begin{array}{l}29.0 \\
(20.1- \\
50.0)\end{array}$ & $\begin{array}{l}27 \\
(22.0- \\
39.5)\end{array}$ & $\begin{array}{l}338.0 \\
(248.0- \\
437.9)\end{array}$ & - & - & $\begin{array}{l}31.6(30.2- \\
34.5)\end{array}$ & $\begin{array}{l}15.5 \\
(10.5- \\
21.3)\end{array}$ \\
\hline $\begin{array}{l}\text { Xiaobo } \\
\text { Yang } \\
(41)\end{array}$ & China & $\begin{array}{l}\text { cross } \\
\text { section } \\
\text { al }\end{array}$ & $\begin{array}{l}52 \\
(35 / 17)\end{array}$ & $59 \cdot 7$ & - & & - & - & - & - & - & - & - \\
\hline $\begin{array}{l}\text { Fei } \\
\text { Zhou } \\
(67)\end{array}$ & China & $\begin{array}{l}\text { cross } \\
\text { section } \\
\text { al }\end{array}$ & $\begin{array}{l}191 \\
(119 / 72)\end{array}$ & $\begin{array}{l}56.0 \\
(46.0- \\
67.0)\end{array}$ & - & & $\begin{array}{l}30.0 \\
(17.0- \\
46.0)\end{array}$ & - & $\begin{array}{l}300.0(234 . \\
0-407.0)\end{array}$ & $0.8(0.4-3.2)$ & - & $\begin{array}{l}32.3(29.1- \\
35.8)\end{array}$ & - \\
\hline $\begin{array}{l}\text { Fating } \\
\text { Zhou } \\
(103)\end{array}$ & China & $\begin{array}{l}\text { cross } \\
\text { section } \\
\text { al }\end{array}$ & $\begin{array}{l}197 \\
(99 / 98)\end{array}$ & 55.94 & 8 & 54.97 & 38.40 & 38.84 & 266.20 & 2309.36 & - & - & 16.31 \\
\hline $\begin{array}{l}\text { Qingxi } \\
\text { an Cai } \\
(104) \\
(2020)\end{array}$ & China & $\begin{array}{l}\text { cross } \\
\text { section } \\
\text { al }\end{array}$ & $\begin{array}{l}417 \\
(198 / 219)\end{array}$ & $\begin{array}{l}47(34- \\
60)\end{array}$ & 22 & & $\begin{array}{l}21(15- \\
31)\end{array}$ & $\begin{array}{l}26.5 \\
(21-35)\end{array}$ & - & - & - & - & - \\
\hline
\end{tabular}




\begin{tabular}{|c|c|c|c|c|c|c|c|c|c|c|c|c|c|c|}
\hline $\begin{array}{l}\text { Zhenyu } \\
\text { Fan } \\
(105) \\
(2020)\end{array}$ & China & $\begin{array}{l}\text { cross } \\
\text { section } \\
\text { al }\end{array}$ & $\begin{array}{l}148 \\
(73 / 75)\end{array}$ & $\begin{array}{l}50(36- \\
64)\end{array}$ & - & $\begin{array}{l}17.75 \\
(8.7- \\
32.38)\end{array}$ & - & - & $\begin{array}{l}224.5(193- \\
283.8)\end{array}$ & & $\begin{array}{l}50(32- \\
84)\end{array}$ & - & & 8 \\
\hline $\begin{array}{l}\text { Yun } \\
\text { Feng } \\
(44) \\
(2020)\end{array}$ & China & $\begin{array}{l}\text { cross } \\
\text { section } \\
\text { al }\end{array}$ & $\begin{array}{l}476 \\
(271 / 205)\end{array}$ & $53(40-64)$ & - & $\begin{array}{l}18.8(5 . \\
23-57)\end{array}$ & - & - & $\begin{array}{l}259(202- \\
356)\end{array}$ & $\begin{array}{l}0.58(0.35- \\
1.48)\end{array}$ & $\begin{array}{l}48(30- \\
80)\end{array}$ & $\begin{array}{l}37.87(32.8- \\
41.84)\end{array}$ & $\begin{array}{l}10.1(7.5- \\
14)\end{array}$ & 9 \\
\hline $\begin{array}{l}\text { Zhicha } \\
\text { o Feng } \\
(106) \\
(2020)\end{array}$ & China & $\begin{array}{l}\text { cross } \\
\text { section } \\
\text { al }\end{array}$ & $\begin{array}{l}564 \\
(284 / 280)\end{array}$ & $\begin{array}{l}47(36- \\
58)\end{array}$ & - & & $\begin{array}{l}20.3 \\
(15.0- \\
30.4)\end{array}$ & $\begin{array}{l}24.3 \\
(19.5- \\
31.5)\end{array}$ & $\begin{array}{l}189.0 \\
(152.0- \\
244.0)\end{array}$ & - & - & $\begin{array}{l}39.0(35.7- \\
42.4)\end{array}$ & $\begin{array}{l}11.9(8.7 \\
-17.6)\end{array}$ & 9 \\
\hline $\begin{array}{l}\text { Sha Fu } \\
(55) \\
(2020)\end{array}$ & China & $\begin{array}{l}\text { cross } \\
\text { section } \\
\text { al }\end{array}$ & $\begin{array}{l}50 \\
(27 / 23)\end{array}$ & - & - & - & - & - & - & - & - & - & - & 9 \\
\hline $\begin{array}{l}\text { Dong } \\
\text { Ji (107) }\end{array}$ & China & $\begin{array}{l}\text { cross } \\
\text { section } \\
\text { al }\end{array}$ & $\begin{array}{l}208 \\
(117 / 91)\end{array}$ & 44 & - & & $\begin{array}{l}24.0 \\
(14.0- \\
37.3)\end{array}$ & - & $\begin{array}{l}234(200- \\
283)\end{array}$ & $\begin{array}{l}0.28(0.19- \\
0.51)\end{array}$ & - & - & - & 9 \\
\hline $\begin{array}{l}\text { Lei Pan } \\
(108)\end{array}$ & China & $\begin{array}{l}\text { cross } \\
\text { section } \\
\text { al }\end{array}$ & $\begin{array}{l}204 \\
(107 / 97)\end{array}$ & 54.9 & - & 57.52 & 35.8 & 35.6 & 318 & 4 & - & 36.1 & 13.3 & 9 \\
\hline $\begin{array}{l}\text { Lowell } \\
\text { Ling } \\
\text { (109) }\end{array}$ & China & $\begin{array}{l}\text { cross } \\
\text { section } \\
\text { al }\end{array}$ & $\begin{array}{l}8 \\
(4 / 4)\end{array}$ & $\begin{array}{l}64.5(42- \\
70)\end{array}$ & - & - & $\begin{array}{l}28(20- \\
45)\end{array}$ & - & $\begin{array}{l}329(266- \\
507)\end{array}$ & - & - & - & $6(5-8)$ & 8 \\
\hline $\begin{array}{l}\text { Ya-nan } \\
\text { Han } \\
(110)\end{array}$ & China & $\begin{array}{l}\text { cross } \\
\text { section } \\
\text { al }\end{array}$ & $\begin{array}{l}25 \\
(12 / 13)\end{array}$ & $\begin{array}{l}44(22- \\
70)\end{array}$ & - & - & - & - & - & - & - & - & - & 8 \\
\hline
\end{tabular}




\begin{tabular}{|c|c|c|c|c|c|c|c|c|c|c|c|c|c|c|}
\hline $\begin{array}{l}\text { Xiufen } \\
\text { g Jiang } \\
(111)\end{array}$ & China & $\begin{array}{l}\text { cross } \\
\text { section } \\
\text { al }\end{array}$ & $\begin{array}{l}55 \\
(27 / 28)\end{array}$ & $\begin{array}{l}45.0 \\
(27.0- \\
60.0)\end{array}$ & - & $\begin{array}{l}8.8(3.5- \\
21.4)\end{array}$ & $\begin{array}{l}21(16- \\
48)\end{array}$ & $\begin{array}{l}24(20- \\
32)\end{array}$ & - & $\begin{array}{l}0.31(0.22- \\
0.63)\end{array}$ & - & $42(39-45)$ & $7(4-10)$ & 9 \\
\hline $\begin{array}{l}\text { Fan } \\
\text { Yang } \\
(46) \\
(2020)\end{array}$ & China & $\begin{array}{l}\text { cross } \\
\text { section } \\
\text { al }\end{array}$ & 92 & - & 15 & $\begin{array}{l}15.6 \\
(4.4- \\
30.3)\end{array}$ & - & - & & - & - & - & - & 8 \\
\hline $\begin{array}{l}\text { Guqin } \\
\text { Zhang } \\
(72) \\
(2020)\end{array}$ & China & $\begin{array}{l}\text { cross } \\
\text { section } \\
\text { al }\end{array}$ & $\begin{array}{l}221 \\
(108 / 113)\end{array}$ & $\begin{array}{l}55(39- \\
66.5)\end{array}$ & - & $\begin{array}{l}53.4 \\
(18.6- \\
113.0)\end{array}$ & $\begin{array}{l}23(16- \\
39)\end{array}$ & $\begin{array}{l}29(22- \\
49)\end{array}$ & $\begin{array}{l}227(174- \\
367)\end{array}$ & $\begin{array}{l}227(129- \\
485)\end{array}$ & - & - & $\begin{array}{l}10.0(8.0- \\
14.2)\end{array}$ & 9 \\
\hline $\begin{array}{l}\text { Rui } \\
\text { Zhang } \\
(112) \\
(2020)\end{array}$ & China & $\begin{array}{l}\text { cross } \\
\text { section } \\
\text { al }\end{array}$ & $\begin{array}{l}120 \\
(43 / 77)\end{array}$ & 45.4 & - & 51.4 & $\begin{array}{l}32.0 \\
(21.0- \\
50.0)\end{array}$ & - & 235.6 & $0 \cdot 5(0 \cdot 3-1 \cdot 3)$ & - & $\begin{array}{l}31.4(28.9- \\
36.0)\end{array}$ & - & 9 \\
\hline
\end{tabular}


Table 2. Summarized Pooled values of Considered findings

\begin{tabular}{|c|c|c|c|c|c|c|c|c|c|}
\hline \multirow[t]{2}{*}{ Variable } & \multicolumn{3}{|c|}{$\begin{array}{l}\text { All } \\
\text { patients }\end{array}$} & \multicolumn{3}{|c|}{ Severe } & \multicolumn{3}{|c|}{ Non-severe } \\
\hline & $\begin{array}{l}\mathrm{N} \text { of } \\
\text { study }\end{array}$ & I-squared & $\mathrm{ES} \%(95 \% \mathrm{CI})$ & $\begin{array}{l}\mathrm{N} \text { of } \\
\text { study }\end{array}$ & I-squared & $\mathrm{ES} \%(95 \% \mathrm{CI})$ & $\begin{array}{l}\mathrm{N} \text { of } \\
\text { study }\end{array}$ & I-squared & $\mathrm{ES} \%(95 \% \mathrm{CI})$ \\
\hline Clinical Outcomes & - & - & - & - & - & - & - & - & - \\
\hline Discharged & 32 & 99.86 & $50(35-65)$ & 12 & 98.07 & $29(21-37)$ & 7 & 99.94 & $43(1-84)$ \\
\hline Death & 29 & 99.69 & $16(1-31)$ & 14 & 99.87 & $50(39-60)$ & 4 & 43.21 & $0(0-1)$ \\
\hline Hospitalization & 23 & 99.77 & $80(72-88)$ & - & - & - & - & - & - \\
\hline ICU admission & 32 & 99.93 & $27(9-44)$ & - & - & - & - & - & - \\
\hline Laboratory findings & - & - & - & - & - & - & - & - & - \\
\hline Increase in ALT & 20 & 91.30 & $17(13-21)$ & 10 & 97.47 & $38(18-58)$ & 6 & 97.09 & $30(16-44)$ \\
\hline Increase in AST & 19 & 92.59 & $18(14-23)$ & 11 & 94.03 & $48(34-63)$ & 8 & 90.79 & $21(13-29)$ \\
\hline Increase in total bilirubin & 8 & 90.69 & $12(7-17)$ & 4 & 66.67 & $17(9-25)$ & 2 & - & $10(7-12)$ \\
\hline Decrease in albumin & 6 & 99.87 & $44(0-88)$ & 3 & - & $36(4-67)$ & - & - & - \\
\hline Increase in C-Reactive Protein & 18 & 96.66 & $53(43-62)$ & 10 & 96.07 & $78(69-88)$ & 7 & 98.57 & $55(36-73)$ \\
\hline Increase in LDH & 18 & 98.23 & $36(25-47)$ & 9 & 97.36 & $75(62-87)$ & 4 & 71.85 & $39(28-49)$ \\
\hline Increase in ESR & 9 & 91.90 & $57(44-70)$ & - & - & - & - & - & - \\
\hline Increase in D-dimer & 17 & 97.97 & $35(24-47)$ & 9 & 94.70 & $79(70-89)$ & 6 & 96.07 & $28(14-41)$ \\
\hline Comorbidities & - & - & - & - & - & - & - & - & - \\
\hline Hypertension & 34 & 95.26 & $24(19-29)$ & 23 & 85.64 & $38(31-45)$ & 15 & 88.58 & $13(9-17)$ \\
\hline Diabetes & 35 & 96.02 & $15(11-18)$ & 22 & 97.85 & $26(11-40)$ & 12 & 89.48 & $7(4-10)$ \\
\hline Cardiovascular disease & 32 & 88.05 & $10(8-12)$ & 20 & 76.78 & $16(12-20)$ & 10 & 52.24 & $4(3-6)$ \\
\hline Respiratory system disease & 26 & 62.40 & $3(2-4)$ & 15 & 60.21 & $6(4-9)$ & - & - & - \\
\hline
\end{tabular}




\begin{tabular}{|c|c|c|c|c|c|c|c|c|c|}
\hline Chronic liver disease & 25 & 75.59 & $3(2-4)$ & 16 & 74.89 & $6(3-9)$ & 10 & 81.36 & $4(1-6)$ \\
\hline Pneumonia & 3 & - & $35(-28-98)$ & - & - & - & - & - & - \\
\hline Cerebrovascular disease & 18 & 79.34 & $3(2-4)$ & 12 & 64.03 & $7(4-9)$ & 6 & 0.97 & $1(1-2)$ \\
\hline Digestive system disease & 9 & 74.83 & $4(2-6)$ & 2 & - & $12(5-19)$ & 2 & - & $8(3-12)$ \\
\hline Endocrine system disease & 7 & 78.60 & $8(4-12)$ & - & - & - & - & - & - \\
\hline Chronic kidney disease & 19 & 51.48 & $1(1-2)$ & 14 & 0 & $3(2-4)$ & 5 & 0 & $0(0-1)$ \\
\hline CNS disorders & 4 & 0 & $1(0-3)$ & - & - & - & - & - & - \\
\hline Immunodeficiency & 7 & 51.54 & $1(0-1)$ & 3 & - & $7(-2-17)$ & 5 & 0 & $0(0-1)$ \\
\hline Malignancy & 28 & 99.64 & $6(1-11)$ & 12 & 21.94 & $3(2-5)$ & 8 & 17.18 & $1(1-2)$ \\
\hline \multicolumn{10}{|l|}{ Complications } \\
\hline Liver toxicity & 13 & 95.35 & $20(14-26)$ & 7 & 97.23 & $41(19-62)$ & 2 & - & $17(13-20)$ \\
\hline Acute kidney injury & 6 & 84.51 & $8(4-13)$ & 5 & 68.57 & $7(2-13)$ & 3 & - & $2(0-4)$ \\
\hline Shock & 6 & 70.94 & $3(1-5)$ & 3 & - & $11(-3-24)$ & - & - & - \\
\hline $\begin{array}{l}\text { Acute respiratory distress } \\
\text { syndrome }\end{array}$ & 6 & 95.69 & $28(15-40)$ & 5 & 97.68 & $67(44-90)$ & - & - & - \\
\hline
\end{tabular}

